Georgia State University

ScholarWorks @ Georgia State University

$11-1-2017$

\title{
CLEP Me Out of Here: The Impact of Prior Learning Assessments on College Completion
}

\author{
Angela Boatman \\ Vanderbilt University \\ Michael Hurwitz \\ College Board \\ Jason Lee \\ Tennessee Higher Education Commission \\ Jonathan Smith \\ Georgia State University
}

Follow this and additional works at: https://scholarworks.gsu.edu/uwrg_workingpapers

\section{Recommended Citation}

Boatman, Angela; Hurwitz, Michael; Lee, Jason; and Smith, Jonathan, "CLEP Me Out of Here: The Impact of Prior Learning Assessments on College Completion" (2017). UWRG Working Papers. 115.

https://scholarworks.gsu.edu/uwrg_workingpapers/115

This Article is brought to you for free and open access by the Usery Workplace Research Group at ScholarWorks @ Georgia State University. It has been accepted for inclusion in UWRG Working Papers by an authorized administrator of ScholarWorks @ Georgia State University. For more information, please contact scholarworks@gsu.edu. 


\section{W. J. Usery Workplace Research Group Paper Series}

Working Paper 2017-11-1

November 2017

\section{CLEP Me Out of Here: The Impact of Prior Learning Assessments on College Completion}

Angela Boatman

Vanderbilt University

Michael Hurwitz

College Board

Jason Lee

Tennessee Higher Education Commission

Jonathan Smith

Georgia State University 
CLEP Me Out of Here: The Impact of Prior Learning Assessments on College Completion

\author{
Angela Boatman, Vanderbilt University \\ Michael Hurwitz, College Board \\ Jason Lee, Tennessee Higher Education Commission \\ Jonathan Smith, Georgia State University
}

November 2017

\begin{abstract}
This paper estimates the impact of the College Level Examination Program (CLEP) examination, a collegelevel exam that offers credit for student mastery of a content area in lieu of completing a course. Using a regression discontinuity design, we find that passing a CLEP exam leads to a 17 percent (5.7 percentage points) increase in associate degree completion for students at two-year colleges and a 2.6 percent (1.2 percentage point) increase in bachelor's degree completion for students at four-year colleges. CLEP also serves and impacts subpopulations historically hard to track in educational data. For example, two-year college enrollees who earn a credit-granting CLEP score and are in the military, older than 24, and were home schooled are 18.1, 19.5, and 62.8 percent more likely to obtain an associate degree, respectively. The impacts from this inexpensive, credit-producing intervention are at least as large in magnitude as most other programs designed to improve degree completion.
\end{abstract}

*The views do not reflect those of the College Board. Michael Hurwitz is a full time employee of the College Board. Jonathan Smith was formerly a full-time employee and currently acts in a consulting capacity. Jason Lee was a summer intern. Angela Boatman has no connections to the organization. 


\section{Introduction}

Despite sustained growth in college enrollment rates, degree completion remains a persistent problem in American postsecondary education. Sixty percent of first-time, full-time students who began seeking a bachelor's degree at a four-year college in the fall of 2008 completed their degree by 2014 (U.S. Department of Education, 2016). Among students beginning at a public community college in 2008, only 20 percent received an associate's degree within three years (U.S. Department of Education, 2014). Over time, these percentages amount to approximately 31 million students who enrolled in college during past 20 years departing without a degree or certificate (Shapiro et al., 2014). Degree completion rates remain even lower for underrepresented minorities, part-time, adult, and military veteran students.

There is no shortage of research on interventions or policies aimed at improving completion rates. It is very common to see null to modest impacts of a policy or intervention in the commonly researched areas such as college costs (Bettinger, 2015; Castleman and Long, 2016; Dynarski, 2002; Scott-Clayton, 2011) or counseling and student support (Bettinger et al., 2012; Castleman and Page, 2016). Take, for example, the U.S. Department of Education's Upward Bound program. This program, which serves approximately 60,000 low-income first-generation students per year at a cost of approximately $\$ 4,200$ per participant (U.S. Department of Education, 2015), was shown to have no impact on postsecondary degree attainment (Seftor, Mamun, and Schirm, 2009). While it is difficult to move the degree attainment needle, there are a few interventions that find substantial impacts. One recent example is the City University of New York (CUNY) Accelerated Study in Associate Programs (ASAP) program, an intensive college counseling and financial assistance program. Research suggests ASAP nearly doubled associate degree rates, but at the substantial cost of approximately $\$ 5,400$ per student (Scrivener et al., 2015). These findings, while impressive, lead many to wonder whether there exists a more cost effective way to improve college graduation rates. 
This paper investigates the causal impact of the College Level Examination Program (CLEP) on degree completion rates at two-year and four-year colleges. CLEP is a competency-based exam that students can elect to take at any point prior to or during college for an $\$ 85$ fee per exam. A passing score, determined by each institution, allows the student to earn college credit in lieu of taking a course. Credit is accepted at nearly 3,000 two-year and four-year colleges and universities in any of the 33 exams in 5 subject areas: composition and literature, world languages, history and social sciences, science and mathematics, and business.

To estimate the impact of CLEP on degree completion, we use a regression discontinuity design on over 800,000 unique first time exam takers between 2008 and 2015, including many students who are historically hard to track in educational data, such as military personnel and veterans, students older than 24 years of age, and homeschoolers. The design compares students just above and below the collegespecific minimum score threshold for the relevant exam. We find that earning a credit-granting CLEP score increases the probability of receiving a college degree by 5.3 percent ( 3 percentage points). Among students attending a four-year college, earning a credit-granting CLEP score increases the probability of bachelor's completion by 2.6 percent (1.2 percentage points). The effects are even larger for students attending two-year colleges. Earning a credit-granting CLEP score increases the probability of earning an associate degree by 17.3 percent (5.7 percentage points), with even more impressive results among military students (8.6 percentage points or 18.1 percent), and students older than 24 years of age (7.3 percentage points or 19.5 percent), and homeschoolers ( 9.1 percentage points or 62.8 percent). The main results are robust to standard methodological concerns and are visually staggering, particularly for associate's degree completion, as shown in Figure 1.

We then focus on several potential (testable) reasons as to why passing CLEP improves college completion rates so dramatically. First, it is possible that students take CLEP before college and strategically sort into colleges that will assign credit to their score. We categorically rule this out with 
several analyses. Second, passing CLEP scores may signal to students their ability to succeed in college and that confidence may propel them through college. We know students who receive signals regarding their ability before college can shift their enrollment choices (Papay, Murnane, \& Willett, 2017) and major choices (Avery et al., 2017), but it is unlikely that such signals are as powerful after students have been enrolled in college and have received numerous signals of readiness via course grades. We observe the same size impacts for students who first take the CLEP exam late in their college career as those who take CLEP before college or early in college. Since the evidence is not consistent with behavioral responses to positive signals, the alternative hypothesis is that students simply require fewer courses to graduate. This would confirm that CLEP, similar to Advanced Placement (Smith, Hurwitz \& Avery, 2017), helps to propel students through college by reducing required coursework. Finally, we show that success on CLEP begets additional CLEP test-taking, but the magnitude of this effect is relatively small, and so we are able to conclude that almost all completion impacts shown in this paper are due to passing a single CLEP exam.

This research adds to several strands of literature. First, it contributes to the vast and growing literature on college completion. The impacts in this study are notable because they are achieved through an extremely low cost intervention and are large in magnitude, particularly for associate's degree seeking students. Under almost any set of assumptions, the $\$ 85$ cost is small relative to the benefits. ${ }^{1} \ln$ fact, our conservative cost-benefit analysis shows that the expected benefits of the exam are thousands of dollars. This is important for institutions, including the Department of Defense which pays for interested members of the military to take CLEP. Second, there is a more narrow, but related, literature on the impacts of course requirements on degree completion, including the negative impact of remediation (e.g., Bettinger, Boatman, \& Long, 2013) and the positive impact of earning college credit while in high school through Advanced Placement (e.g., Smith, Hurwitz, \& Avery, 2017). Even more narrowly defined, a third strand of literature addresses competency-based, and portfolio assessment credit-earning models and prior

\footnotetext{
${ }^{1}$ During the years covered in this study, the cost of CLEP was $\$ 80$.
} 
learning assessments (e.g., Klein-Collins \& Wertheim, 2013). However, most of this literature discusses promises and pitfalls of these approaches. Our paper is the first to find the causal impact of one such widespread model. By obtaining causal estimates, we are able to contribute to the discussion on the costs and benefits of higher education's role as both a creator and certifier of human capital and the optimal design of a college's curriculum, an idea we discuss further in the conclusion.

\section{Background}

\subsection{Prior Learning Assessments}

CLEP is one of several initiatives in higher education focused on granting credits for prior knowledge. Many of these programs, including CLEP, are considered both a prior learning assessment (PLA) and a form of competency-based testing (CBT) (Klein-Collins, 2010; Klein-Collins \& Wertheim, 2013). Unlike competency-based testing, which focuses more on end-of-course student competency outcomes, CLEP and other PLA programs measure a student's prior learning and mastery of a college-level subject through an examination. If the student is able to demonstrate sufficient knowledge on the subject matter, she typically receives college course credit without ever enrolling in the course (CLEP, 2016). In this sense, PLA programs may allow students to save both time and tuition dollars by demonstrating mastery in a course and earning college credits as a result.

PLA programs are designed to reduce time to degree, thereby reducing a variety of costs, including the student's tuition, foregone wages, and taxpayer's subsidies-and ultimately resulting in a lower cost to degree (Bell \& Valliani, 2014; Complete College America, 2011). If costs are an important barrier to college persistence and completion, then programs that reduce costs may lead to higher rates of degree attainment. The primary mechanism through which prior learning assessments work may be in lowering the cost borne by the student compared to earning degree credit through traditional, semester-long means. Prior research on reducing students' cost of college through need-and merit-based financial aid 
programs suggests that reducing the costs of attaining a degree results in greater persistence and degree completion rates (Bettinger; 2004; Dynarski, 2008). Academic momentum, or the speed at which students are able to complete their college coursework, is an important predictor of bachelor's degree completion (Adelman, 1999; 2006; Attewell, Heil, \& Reisel 2012). As the amount of time students spend successfully earning credits each term increases, the likelihood of graduation also increases (DesJardins, Ahlberg, \& McCall 2006).

\subsection{CLEP}

The College Level Examination Program (CLEP) was the first widespread competency-based program of its kind used in postsecondary education. CLEP was developed by the College Board in 1967, as an extension of the Comprehensive College Test designed by Educational Testing Service (ETS) in 1965. Today, CLEP offers 33 exams in 5 subject areas, and exam scores are accepted at nearly 3,000 colleges and universities, each of which sets its own policy for accepting credits earned through CLEP examinations (College Level Entrance Exam, 2016). Students who pass a CLEP exam may earn three or more credits; however, the amount a student can earn on an individual CLEP exam varies with each college. Additionally, colleges are able to determine the minimum qualifying score to earn credit, and also place restrictions on the number of credits a student may earn through CLEP or the circumstances under which a student may earn CLEP credit. For example, some colleges may not grant CLEP credit towards the core curriculum, or may not accept all of the 33 exams.

CLEP exams are administered at 1,800 computer test centers across the country, including several international colleges and military-based testing sites. The exams are primarily multiple choice and the majority are timed at 90-minutes. Colleges typically accept CLEP credits as transfer credit, exemptions from pre-requisite courses, or elective credits. The cost for taking a CLEP exam in the years of this study was $\$ 80$ (\$85 today), but the exam is available free of charge for all qualifying U.S. Armed Forces personnel through the Defense Activity for Non Traditional Education Support (DANTES) program. The current 
waiting period for retaking a CLEP exam in the same subject is three months. Prior to October 2014, the waiting period to retake an exam was six months.

As shown in Appendix Table 1, the most popular CLEP exam is the Spanish Language exam, with nearly a quarter of the test-takers ( 200,000 students) between 2008-15 taking the exam. The second and third most popular exam is Analyzing and Interpreting Literature and College Algebra, respectively. Many of the exams are typical gateway college-level courses, such as English, Biology, and Mathematics courses, as well as several foreign language exams.

Evidence on the effectiveness of CLEP and other competency-based testing programs on student success is limited. The descriptive research suggests that students with prior-learning assessments (PLA), such as CLEP, had better academic outcomes than students who did not take a PLA (Klein-Collins, 2010; Barry, 2013). These studies, however, typically do not control for issues of selection into who takes a PLA in the first place. We are aware of only one study focused solely on the effectiveness of receiving CLEP credits on student persistence and degree completion that also attempts to address issues of selection. Using a matching design to assess the effect of CLEP on college student outcomes at a single institution, Scammacca (2003) finds that students earning credits through a CLEP exam had higher college GPAs than non-CLEP- earning students with similar entrance exam scores and high school rank, and compared to students receiving credit through comparable AP exams. This study still only examines students receiving CLEP credits compared to similar students who may or may not have chosen to take a CLEP exam. The ideal comparison group for studying the impacts of earning CLEP credits are those students who also elected to take a CLEP exam, but just barely missed the cutoff for receiving credit. We contribute to the literature by adopting this analytic strategy and causally estimating the impacts of earning credit-granting CLEP scores on college completion.

\section{Data and Empirical Strategy}




\subsection{Data}

We use student-level data for all those who took a CLEP exam from 2008-15. This data set is collected and maintained by the College Board (CB) and includes information on every exam taken during this time period, along with self-reported information on student age, race, gender, military status, and home school status. Throughout our analyses, we focus on a student's first CLEP score to avoid concerns with endogenous retaking. ${ }^{2}$

In order to examine postsecondary outcomes, we merge the CLEP data with enrollment and graduation data from the National Student Clearinghouse (NSC) through 2015. As of 2015, over 3,600 colleges and universities participate in the NSC, comprising over $98 \%$ of all students enrolled in American postsecondary institutions. This coverage has changed over time with approximately $91 \%$ of all students enrolled in the postsecondary system accounted for during the 2011-12 academic year (Dynarski, Hemelt \& Hyman, 2015). Because the majority of students take the CLEP while enrolled in college, we include each of the seven cohorts of CLEP test-takers in the analyses, although the results are insensitive to eliminating more contemporary cohorts who had less time to complete degrees.

Test score thresholds for college credit are retrieved from two sources: the Annual Survey of Colleges (ASC) and the CLEP official website. ${ }^{3}$ The ASC contains detailed information on a number of institution-level characteristics including credit-granting minimum scores separately for each CLEP subject. We then compare these cutoff scores across ASC surveys to those scores found on the CLEP website both to determine how static they are across time and to include any score cutoffs that institutions failed to report in a given ASC year or on the website. The modal threshold, capturing 80

\footnotetext{
${ }^{2}$ A separate but related issue is students taking multiple exams on the first day they sit for a test. While this only represents $3 \%$ of students, we run specification checks where we eliminate these students and find results that are identical to those presented.

${ }^{3}$ The ASC no longer asks respondents to report minimum CLEP credit-granting scores.
} 
percent of the CLEP cutoffs at both two-year and four-year colleges, is 50, with approximately 20 percent of institutions reporting thresholds other than 50, primarily between 40 and 60 .

\subsection{Descriptive Statistics}

Table 1 shows the descriptive statistics of the sampled CLEP test-takers. Nearly a quarter of the sample identified as Hispanic or Latino and 55 percent self-identified as white. Black/African American and Asian students comprise 9 and 5 percent of the sample, respectively. The sample is evenly split between males and females and the average age of sampled students is 26 at the time of their first exam. Students affiliated with the U.S. military make up one quarter of the sample and home-schooled students contribute 4 percent.

In this study, we primarily consider a student's first CLEP score to examine postsecondary outcomes because, as we show, success on CLEP induces students to take more CLEP exams. The average sampled student took 1.58 CLEP exams, with 73 percent of students only taking one exam. On the 20-80 scale, average CLEP scores of sampled students are about 57, and about 26 percent of students first took the CLEP prior to enrolling in any postsecondary institution. More than two-thirds of students enrolled at a four-year college during or immediately after taking their first CLEP exam and another 22 percent enrolled at a two-year college. Nearly 80 percent of enrolling students attend a postsecondary institution for which a score of 50 or higher on the relevant CLEP would earn them college credits. Slightly more than 70 percent of CLEP test-takers are eligible for college credit as a result of meeting these minimum thresholds.

More than half ( 52 percent) of sampled students ultimately earned a postsecondary degree by 2015. The majority of degree recipients earned a bachelor's degree- 37 percent of the total sample had completed a BA/BS by 2015. About one-fifth of sampled students earned an associate's degree. Some students earned both associate's degrees and bachelor's degrees, and as a result, the sum of the BA and AA attainment rates exceeds the overall degree attainment rate of 52 percent. 


\subsection{Empirical Methodology}

We use a regression discontinuity design (RDD) that compares students who just barely attain a credit-granting score to those seemingly identical students who just barely missed the credit-granting threshold. In our main analyses, we restrict to the first exam for each test-taker in our sample to account for potentially endogenous retaking of the test. To measure the impact of earning minimum CLEP creditgranting scores, we estimate the following equation:

$$
\text { Outcome }_{i}=\beta_{0}+\beta_{1} \text { Credit }_{i j}+\beta_{2} \text { Dist }_{i j}+\beta_{3} \text { Credit }_{i j} * \text { Dist }_{i j}+X_{i j}+\varepsilon_{i j}
$$

where Outcome $_{i j}$ is the outcome variable of interest, often an indicator of degree attainment, for student $i$ who took exam subject $j$. Dist $t_{i j}$ is the number of points away from the college-specific credit-granting threshold and serves as our forcing variable that is re-centered at zero. Credit $_{i j}$ is an indicator for meeting or exceeding the designated threshold for college course credit. In other words, this variable equals one if Dist $_{i j} \geq 0$ and zero otherwise. We include the interaction of these two terms to allow for different slopes on each side of the threshold. Finally, $X_{i j}$ includes a vector of covariates (e.g., race, sex, age, and military status) that we only use in robustness checks. The coefficient of interest, $\beta_{1}$ in equation (1) represents the causal effect of earning college credit through the CLEP on an outcome, such as degree attainment. $^{4}$

\footnotetext{
${ }^{4}$ Alternatively, we can use two-stage least squares to estimate the impact of passing one additional CLEP exam on an outcome by instrumenting total exams passed with being above the score threshold. As we show in Appendix Table 3, the first stage is between 0.95 and 1, depending on the specification, such that the second stage coefficients revert to the reduced-form coefficients in equation (1). This is because the retaking for those below the threshold is offset by the fact that those who get credit are induced to take additional CLEP exams. We proceed by only presenting the reduced-form estimates.
} 
We estimate equation (1) using local linear regression with triangular kernels utilizing the Imbens and Kalyanaraman (2012) optimal bandwidth procedure. ${ }^{5}$ As is common in studies utilizing an RD design, we explore a number of specifications. Our estimates are consistent across a variety of bandwidth and kernel combinations, as evidenced in Appendix Table 4 and discussed in Section 4.3. We also test the sensitivity of our results to two alternative forcing variables. The first is the distance from 50 , which is the most common credit-granting threshold across all subjects and colleges. The second alternative forcing variable represents the distance from the credit-granting score at the college where the student took the CLEP exam, which is not necessarily (but often is) the same college the student attends. We also test the validity of the research design with density and covariate balance tests, as described below.

\section{Results}

\subsection{Continuous Density and Covariate Balance}

In order to obtain unbiased estimates, there must be no strategic manipulation around the cut scores. Students falling short of minimum credit-granting scores, which are generally 50 , may retake the CLEP to achieve this score. We remove any challenges from endogenous retaking by using the student's CLEP score on their first attempt. Additional manipulation would require unrealistic efforts and abilities among exam takers to know the minimum number of questions needed to achieve certain scores and complete confidence that all answers to these questions are correct.

Such strategic manipulation is generally visualized as bunching of observations at or just above the credit-granting boundary. In Figure 2, we show the density of observations plotted against the distance to the relevant college-specific credit-granting threshold, with alternate forcing variables shown in Appendix Figure 1. It is visually evident that the density of observations is continuous in the vicinity of

\footnotetext{
${ }^{5}$ Lee and Card (2008) recommend clustering standard errors on the forcing variable when that variable is discrete. We find that such clustering actually results in smaller standard errors, so we opt instead to use heteroscedasticity robust standard errors, which leads to more conservative inferences.
} 
the minimum credit-granting score, which is centered at zero. Formal tests of continuous density proposed by McCrary (2008) confirm that there exist no statistically significant discontinuities in density and are presented at the top of Table 2. None of these discontinuities, expressed as log-differences in height across the boundaries, reach levels of statistical significance.

We also test for discontinuities in covariates across credit-granting boundaries. A preponderance of imbalances on student-level covariates might also be indicative of strategic sorting. The parameters presented in Table 2 are estimated by fitting equation (1) and replacing the college enrollment and completion outcomes with student-level covariates. ${ }^{6}$ In general, Table 2 shows that covariates are balanced across the threshold. Although there is a smattering of statistically significant differences, these are small in magnitude and their prevalence is akin to what one might expect through random chance.

In the final row of Table 2, we test for collective differences in covariates across the CLEP boundaries that might compromise this study's design. We accomplish this by regressing CLEP scores on the entire set of covariates presented in Table 2. We then treat the predicted CLEP scores as the outcome variable in equation (1). Discontinuities in predicted CLEP scores across credit-granting boundaries would signal differences in student-level characteristics that could bias estimates. There are no significant differences in predicted CLEP scores across boundaries from models constructed from all three forcing variables.

\subsection{Main Results - College Completion}

In Table 3, we show the impact of meeting the CLEP threshold for college credit on the probability of earning an associate's degree, bachelor's degree or either of these degrees by 2015. In the first three columns, we show OLS estimates in which we regress the outcomes on the total credit-granting CLEP

\footnotetext{
${ }^{6}$ We use a triangular kernel with a bandwidth of 7 , which is approximately equal to the bandwidths obtained from applying the Imbens-Kalyanaraman (2012) approach to fitted models where college completion is the outcome of interest.
} 
scores. In the next three columns, we show reduced-form results from equation (1). Each panel shows the results of these analyses after conditioning on initial college-going behavior. ${ }^{7}$

The reduced-form estimates in Panel A show that credit eligibility through CLEP increases overall degree attainment by 3 percentage points, which is a weighted average of the 3.4 percentage point impact on two-year students and 2.9 percentage point impact on four-year students. When overall degree attainment is the outcome of interest, the OLS findings are nearly identical to the reduced-form findings.

In the next panels of Table 3, we consider associate and bachelor's degrees separately as outcomes, conditioning on the college sector in which the student enrolls. This is relevant because many students starting at a two-year college are not pursuing a four-bachelor's degree and many students at four-year colleges are not pursuing associate's degrees. Reduced-form estimates show that the impact of getting a credit-granting CLEP score on the probability of attaining an associate's degree is 3 percentage points. Conditioning on enrollment at two-year colleges reveals an impact of 5.7 percentage points. With a control mean of 32.9 percent, this translates into a 17 percent increase in the probability of earning an associate's degree among two-year college enrollees. OLS estimates on associate's degree completion tend to be downward biased. In the bottom panel, we show that, among students first enrolling in a fouryear college, earning a CLEP credit-granting score increases bachelor's completion by 3 percent (1.2 percentage points).

In Appendix Table 3, we show that parameter estimates are insensitive to two alternate forcing variables: distance from a CLEP score of 50 and distance to the credit-granting threshold at the testing center college. The lone exception to this robustness test involves the Table 3 finding that earning a creditgranting CLEP score for two-year college enrollees decreases the probability of earning a bachelor's

\footnotetext{
${ }^{7}$ An alternative strategy to the reduced form estimates generated from equation (1) is to use an instrumental variables (IV) estimation. As shown in Appendix Table 2, the first stage of this IV is close to one and consequently, the reduced form and IV results are nearly identical. We proceed with discussing the reduced form estimates.
} 
degree by 1.6 percentage points. This claim is no longer supported when the forcing variable is switched from distance to credit-granting CLEP score on the first exam to distance from a score of 50.

We offer visual confirmation of the model-estimated discontinuities in Figure 1, with figures for alternate forcing variables in Appendix Figure 2. The three panels show the probability of earning an associate's degree conditional on first attending a two-year college, the probability of earning a bachelor's degree conditional on first attending a four-year college, and the unconditional probability of earning any degree. Visual discontinuities are sharpest in the panels reflecting associate's degree completion among students first enrolled in two-year colleges, which is consistent with the findings in Table 3.

\subsection{Time to Degree}

In addition to increasing overall completion rates, there is potential for CLEP credits to decrease the time to degree as the number of total courses required for completion is reduced. In this section, we present the regression discontinuity estimates of on-time completion rates as well the number of days enrolled and the number of days enrolled after taking a CLEP exam. For these last two metrics, students failing to complete degrees are excluded. Because the CLEP exams may move marginal students from non-completers to completers with prolonged enrollment spells, it is possible that the completion impacts and impacts on time to degree effectively cancel each other out.

Figure 3 and Table 4 show that this is not the case. Not only does CLEP credit increase completion rates, the students who are completing their degrees are doing so in a shorter period of time. Among students enrolling at two-year colleges, the estimate on reduced time to degree is about 81 days, and students enrolling at four-year colleges who earn CLEP credit experience a decrease in time to degree of nearly one month. Regression discontinuity estimates of on-time associate degree completion among two-year college enrollees (3.5 percentage points) are somewhat lower than associate degree regression discontinuity estimates (5.7 percentage points) when no restrictions are placed on duration of studies. By contrast, estimates on bachelor's degree completion among four-year college enrollees are nearly 
identical between the unrestricted estimates in Table 3 (1.2 percentage points) and estimates of on-time bachelor's degree completion (1.3 percentage points). Estimates of shortened time to degree from passing the CLEP suggests even larger impacts on shortened time to degree for the "always completers"students who would have graduated even in the absence of earning credit through CLEP.

\subsection{Impacts on Retaking and Subsequent Taking}

In Figure 4 and Table 5, we show the estimated discontinuities in retake rates, subsequent exam test taking and total credit-granting CLEP scores using the distance from the college-specific creditgranting threshold on the first exam as the forcing variable. Previous work by Smith, Hurwitz and Avery (2017) has shown that high school juniors who succeed in Advanced Placement go on to take more Advanced Placement exams as seniors. We also find that success on CLEP begets additional CLEP testtaking. Students who barely earn CLEP credit on their first exam are 3 percentage points more likely to take a subsequent exam in a different subject, and on average, take 0.09 subsequent exams. About 9 percent students who just miss the credit-granting CLEP score retake the CLEP exam in that same subject. Together, these effects create a discontinuity of about 0.96 total exams passed at the credit-granting threshold on the first CLEP exam.

\subsection{Effects of Passing Multiple Exams}

The emphasis thus far has been on the impacts of passing a single CLEP exam. Approximately 11 percent of the sample earned credit-granting CLEP scores on two or more exams, and this allows us an opportunity to examine the impacts on degree completion of earning credit on the second exam. Figure 5 and Table 6 show the reduced-form estimates of fitting equation (1), after substituting the forcing variable to represent the distance from the credit-granting threshold on the student's second exam. We separately condition on passing the first exam (columns 1-3 of Table 6) and not earning a credit-granting score on the first exam (columns 4-6 of Table 6). 
Earning a credit-granting score on the student's second exam continues to yield positive impacts on degree completion. Among two-year college-goers who did not pass the first exam, earning credit on the second exam yields an 8.1 percentage point increase in associate's degree completion. We also observe a 6.7 percentage point increase among two-year college enrollees who received a credit-granting score on the first exam. Taken together with the 5.7 percentage point impact of passing the first exam in Table 3, this finding implies that earning two credit-granting CLEP scores increases the probability of associate's degree completion by 12.4 percentage points.

\subsection{Robustness Tests}

Next, we run several robustness tests, including the standard tests associated with RD designs. We relegate these tables to the appendix but describe the tests below. First, in Appendix Table 3, we use alternate forcing variables. The first is the distance from 50 , which is the most common credit-granting threshold across all subjects and colleges. The second alternative forcing variable represents the distance from the credit-granting score at the college where the student took the CLEP exam, which is not necessarily (but often is) the same college the student attends. These two alternative forcing variables alleviate concern about noise introduced from changing or incorrectly reported credit-granting policies. Results are insensitive to the choice of running variable.

Our results are also insensitive to bandwidth and choice of rectangular versus triangular kernels, as well as the inclusion of covariates and higher order expressions of the forcing variable. In Appendix Table 4, we show this insensitivity, as completion impacts are generally stable across a wide range of specifications. Finally, we show that results are insensitive to the removal of students who may not have had enough time to graduate from college (final column of Appendix Table 5). Finally, due to the large number of students taking the Spanish Language exam (25 percent of the sample), we test whether the results differ for Hispanic versus non-Hispanic students (Appendix Table 6). The effects on earning an 
associate's Degree for non-Hispanic students passing the Spanish Language exam hold, although become non-significant for Hispanic students.

\section{Mechanisms}

\subsection{Strategic College Enrollment}

It is feasible that students take a CLEP exam, receive a score, and then strategically choose a college based on their score and the college's credit policy. In this subsection, we rule out that possibility through several analyses. In Table 7, we show that students who take the CLEP do not change the sector of college that they enroll in or whether they enroll in college at all. The table shows the impacts of scoring 50 or higher (top panels) and an alternate forcing variable (distance from minimum credit-granting threshold at the college where the student took the CLEP) on college enrollment. In the first three columns of Table 7, we eliminate the students who took the CLEP while enrolled in college before determining whether achieving certain CLEP benchmark scores influences student enrollment. We find no effect on student enrollment using forcing variables representing distance from scores of 50 or cutoffs maintained by testing center colleges. When already enrolled students are folded into the analyses, we find some evidence of CLEP scores shifting enrollment between the two- and four-year sectors (columns 5 and 6), but these results do not hold when the forcing variable is set as distance from the testing center threshold. Figure 6 represents two and four-year college enrollment by the two forcing variables referenced above. Neither the whole sample (Figure 6a), nor the removal of students who were enrolled in college while taking the CLEP (Figure 6b), reveal any visual discontinuities at the relevant thresholds.

In Appendix Table 5, we further demonstrate that strategic enrollment is not driving this paper's results. Column 1 of this table restates the main parameter estimates from Table 3. In the next column we only consider the sample of students enrolled in college while taking the CLEP to completely eliminate the possibility of strategic enrollment. Parameter estimates are nearly identical between columns 1 and 
2. In column 3, we include fixed effects for colleges to rule out the influences of students shifting between colleges within the two-year/four-year college sectors. Under these specifications, we see a modest decrease in the impact of associate's degree attainment, with overall degree impacts and bachelor's degree impacts remaining unchanged.

\subsection{Signal or Credit Policies}

Next, we explore how the impact of CLEP varies by the length of time students have been enrolled in college before taking the exam. Students who take CLEP early in their college career have had little interaction with college coursework and grades and may find CLEP to be a signal of their college readiness and overall ability to succeed. On the other hand, students well into their college career have received numerous signals and so passing CLEP is unlikely to change the students' perceptions of their college readiness. Therefore, if the impact is larger for students who take the exam earlier in their college career, all else equal, there is evidence consistent with the signaling story.

To test this hypothesis, we split the sample into bins based on the length of postsecondary enrollment prior to taking the CLEP, excluding all students who took the CLEP before enrollment. In the first panel of Table 8, we show the RD estimates for whether the student earned any degree. In the next two panels we show the RD estimates on bachelor's completion and associate's completion, conditioning on the students first attending four-year and two-year colleges, respectively. There is no systematic pattern suggesting that students who take a CLEP exam later in their postsecondary careers experience larger completion effects from passing the CLEP exam, compared to students taking the exam earlier in their postsecondary careers. For example, students who took the CLEP exam between one half of a year and one year after enrolling at college, experienced the same degree completion effect from passing CLEP ( $\approx 4$ percentage points) as students who took the CLEP between 2 and 4 years after first enrolling. Panels separately showing effects on bachelor's completion and associate's completion similarly reveal an 
absence of patterns in RD parameter estimates by time elapsed between first enrollment and the CLEP date.

Combined, the results of Table 8 provide two important contributions. First, the consistency of impact estimates across different stages of students' postsecondary careers suggest that credit reduction policies, rather than a behavioral response from signals of college readiness, are responsible for the observed impacts in this paper. A second, perhaps less likely, hypothesis behind the completion impacts shown thus far is that students who take the CLEP exam at the end of their postsecondary careers and earn a non-passing score leave college without a degree. Under this scenario, we would expect the statistically significant results to be concentrated near the 3 to 4 year mark for four-year college enrollees and after the one year mark for two-year college enrollees. Table 8 shows that this is not the case.

\section{Heterogeneous Effects}

In this section, we consider the impacts of credit from CLEP for several subgroups, including military students, underrepresented minorities, non-traditionally aged students, and homeschoolers. To do so, we separately estimate equation (1) for subsamples of the entire sample. Results are reported in Table 9 and the corresponding Figure 7.

Military students are a particularly notable group in our sample. Nearly 25 percent of the sample is affiliated with the military, translating into more than 200,000 observations. Our dataset is one of the few in higher education with such a high concentration of military students, and, as a result we are able to estimate effects for this subgroup with great precision. CLEP is a popular exam among this nontraditional set of students because the Department of Defense covers fees for active military members through the Defense Activity for Non-Traditional Education Support program. Our analyses demonstrate a great return on investment for the federal government. 
In the first column of Table 9, we find that students affiliated with the U.S. military experience a 12 percent (6.4 percentage point) increase in the probability of degree completion as a result of earning a credit-granting CLEP score. The effect on bachelor's completion is 11 percent (2.6 percentage points) and 18 percent (8.6 percentage points) for associate's degree completion. The impact on associate's degree attainment is among the largest percentage point impacts throughout this paper and suggests that subsidizing CLEP exams propels veterans towards degrees.

Next, we consider the impact of receiving credit from CLEP exams on the college completion rates of underrepresented minorities. The coefficients on Black and Hispanic students are not significantly different than those for white students. This suggests that CLEP credit can help all students, including minority students, complete college.

In Column 10 of Table 9, we show the impact of CLEP credit on non-traditional age students, defined as students who are 25 or older. Despite the fact that nearly 40 percent of students enrolled in postsecondary institutions fit into this non-traditional category, these students are rarely the focus of higher education research. ${ }^{8}$ Table 9 shows that the impacts for these students are larger than for traditional-aged students. The 20 percent (7.3 percentage points) increase in associate's degree completion is particularly large given that these students tend to experience lower rates of degree attainment. To our knowledge, there are no interventions that have an impact as sizable as this one for non-traditional aged students.

Finally, the last column shows the impact of CLEP credit on homeschoolers. Again, this population is seldom the subject of research because they are few in numbers and often not appropriately identified. With over 28,000 homeschooled students, our data set represents one of the largest samples of such students. We find that the impact of CLEP credit on associate's degree attainment for homeschooled students is 9.1 percentage points. Homeschooled students enrolled at two-year colleges have some of the

\footnotetext{
${ }^{8}$ Data come the NCES 2015 Digest of Education Statistics (Table 303.40).
} 
lowest degree attainment rates, and this 9.1 percentage point increase represents a staggering 63 percent increase in associate's degree completion.

\section{Conclusion}

Attaining a credit-granting CLEP score leads to a significant increase in the probability of earning a postsecondary degree. These results-while persistent across the population of CLEP participants-are most pronounced for students enrolled in associate's degree programs and those student subpopulations who have traditionally underperformed in the postsecondary system. These findings have important policy implications, as they suggest that a large prior learning assessment program with national reach, such as CLEP, has the potential to serve as one of the most cost-effective ways to increase degree attainment rates in the U.S., particularly among underrepresented students. The effects of the CLEP program are promising, and, at the very least, warrant further investigation into the use of prior learning assessments as a tool for college success.

From the student side, CLEP passes a cost benefit analysis under almost any reasonable set of assumptions. At a cost of $\$ 80$ per exam during the years of this study, the expected benefit for students at two-year colleges and four-year colleges is around $\$ 2,000$ and $\$ 4,000$, respectively. ${ }^{9}$ Future research should more carefully investigate these relationships with linked student level data, loan repayment, and labor market outcomes.

It is also worthwhile to put the impact of CLEP in context by comparing the effect sizes of the program to those achieved through other interventions. One of the interventions with the largest impacts on associate's degree attainment has been CUNY's ASAP, discussed in this paper's introduction. We focus

\footnotetext{
${ }^{9}$ We calculated this number using the lifetime earnings premiums of bachelor's degree recipients $(\$ 298,348)$ and associate's degree recipients $(\$ 82,641)$ relative to individuals with some college from the 2016 Education Pays. Among the approximately 811,000 students in the sample, 403,000 students enrolled in four-year colleges passed a CLEP and 137,000 students enrolled at a two year colleges passed a CLEP. Of these students, about 4,850 earned bachelor's degrees because they passed the CLEP (calculated as $0.012 \times 403,000$ ) and 7,800 earned associate's degrees because they passed the CLEP. The total earnings from CLEP are calculated as $4,850 \times \$ 82,641+7,800 \times$ $\$ 298,348$.
} 
on this program because the impacts are impressively large (nearly doubling the associate's degree completion rate from 21.8 percent to 40.1 percent) (Scrivener et al., 2015). The success of CUNY's ASAP was tempered by the high costs of $\$ 5,400$ per student (Dynarski, 2015). The completion impact of CUNY ASAP was approximately three times as large as the impact of passing a CLEP among two-year college enrollees (18.3 percentage points versus 5.7 percentage points). However, per student, ASAP is nearly 70 times more expensive than $\operatorname{CLEP}(\$ 5,400$ for ASAP and $\$ 80$ for CLEP). As a high cost, high touch intervention, the CUNY ASAP program offers promising evidence that the completion needle can be moved. However, our CLEP research shows that effective interventions need not come with a hefty price tag.

From the institution side, prior credit may cause concern for colleges and universities that are sensitive to tuition revenue. Administrators may worry about lost revenue from allowing students to place out of introductory coursework. However, these concerns should be weighed against the fact that CLEP credit-granting policies have the potential to increase overall completion rates. This is not trivial in the current education landscape where colleges are increasingly finding themselves accountable for graduation rates.

The results also implicate the role of higher education in the labor market, which is often broken into two categories- signaling and human capital expansion. Compelling students to re-take courses for which they have already demonstrated mastery would add little in the way of human capital. And removing prior learning assessments as an option to move through college could, all else equal, reduce completion rates, which is a signal unto itself (i.e., the "sheepskin effect"). Future research should investigate the counterfactual to taking CLEP so as to better understand this extensive margin, since we only investigate the intensive margin of passing an exam. Regardless, critics of prior learning assessments often take a stance related to signaling and argue that college is intended to be a "personal growth" 
experience. Given the increasing sticker prices of postsecondary institutions, the "personal growth" model may be a luxury reserved for fewer and fewer students going forward.

\section{$\underline{\text { References }}$}

Abraham, K. G., \& Clark, M. A. (2006). Financial aid and students' college decisions evidence from the District of Columbia Tuition Assistance Grant Program. Journal of Human Resources, 41(3), 578610.

Adelman, Clifford (1999). Answers in the toolbox: Academic intensity, attendance patterns, and bachelor's degree attainment. Available http://www2.ed.gov/pubs/Toolbox/toolbox.html. Accessed 23 December 2016.

Adelman, Clifford (2006). The toolbox revisited: Paths to degree completion from high school through college. Washington, DC: U.S. Department of Education.

Aleamoni, L. M., \& Kohen, E. S. (1977). The CLEP General Examination validation program at the University of Illinois from 1970 to 1972. Research in Higher Education, 6(4), 343-353. http://doi.org/10.1007/BF00992178.

Attewell, Paul, Scott Heil, and Liza Reisel (2012). What is academic momentum? And does it matter? Educational Evaluation and Policy Analysis 34(1): 27-44.

Avery, C., Gurantz, O., Hurwitz, M., \& Smith, J. (2017). Shifting college majors in response to Advanced Placement exam scores. Journal of Human Resources, 1016-8293R, published ahead of print May 2, 2017.

Barry, C. L. (2013). A Comparison of CLEP ${ }^{\circledR}$ and Non-CLEP Students with Respect to Postsecondary Outcomes. Research Note 2013-9. College Board.

Bell, A., \& Valliani, N. (2014). The real cost of college: Time \& credits to degree at California State University. Retrieved from: http://realcostofcollegeinca.org/wp-content/uploads/2014/06/RealCost-of-College Full-Report CSU.pdf.

Ben-Yoseph, M., Ryan, P., \& Benjamin, E. (1999). Retention of adult students in a competence-based individualized degree program: Lessons learned. The Journal of Continuing Higher Education, 47(1), 24-30.

Bettinger, E. (2004). How financial aid affects persistence. In College choices: The economics of where to go, when to go, and how to pay for it (pp. 207-238). University of Chicago Press. 
Bettinger, E. (2015). Need-based aid and college persistence. The effects of the Ohio College Opportunity Grant. Education Evaluation and Policy Analysis, 37, 102-119.

Bettinger, E., Boatman, A., \& Long, B.T. (2013). Student supports: Developmental education and other academic programs. The Future of Children, 23, 93-115.

Bettinger, E., Long, B.T., Oreopoulos, P., \& Sanbonmatsu, L. (2012). The role of simplification and information in college decisions: Results from the H\&R Block FAFSA experiment. The Quarterly Journal of Economics, 127, 1205-1242.

Bound, J., Lovenheim, M., \& Turner, S. (2010). Why have college completion rates declined? An analysis of changing student preparation and collegiate resources. American Economic Journal: Applied Economics, 2, 129-157.

Bound, J., \& Turner, S. (2007). Cohort crowding: how resources affect collegiate attainment. Journal of Public Economics, 91, 877-899.

Bowen, W. G., Chingos, M. M., \& McPherson, M. S. (2009). Crossing the finish line: Completing college at America's public universities. Princeton, NJ: Princeton University Press

Brock, T., \& Richburg-Hayes, L. (2006). Paying for Persistence. Early Results of a Louisiana Scholarship Program for Low-Income Parents Attending Community College. MDRC.

Calcagno, J. C., Crosta, P., Bailey, T., \& Jenkins, D. (2007). Stepping stones to a degree: The impact of enrollment pathways and milestones on community college student outcomes. Research in Higher Education, 48(7), 775-801.

Caldwell, E. (1973). Analysis of an Innovation (CLEP). The Journal of Higher Education, 698-702.

Cashin, W. E. (1974). The Relationship of Scores on the Clep General Examinations to Grades. Educational and Psychological Measurement, 34(4), 907-913.

Castleman, B.L., \& Long, B.T. (2016). Looking beyond enrollment: The causal effect of need-based grants on college access, persistence, and graduation. Journal of Labor Economics, 34, 1023-1073.

Castleman, B.L., \& Page, L.C. (2016). Freshman year financial aid nudges: An experiment to increase FAFSA renewal and college persistence. Journal of Human Resources, 52, 389-415.

Cejda, B. (1998). Faculty Collaboration and Competency-Based Curriculum Agreements: Meaningful Links in Transfer Education. Michigan Community College Journal: Research \& Practice, 4(1), 69-78.

Cohodes, S. R. and Goodman, J.S. (2014). Merit aid, college quality, and college completion: Massachusetts' Adams scholarship as an in-kind subsidy. American Economic Journal: Applied Economics,6, 251-285. 
College Level Examination Program (2016). Getting College Credit. Retrieved from: https://clep.collegeboard.org/overview/collegecredit.

Complete College America (2011). Time is the enemy: The surprising truth about why today's college students aren't graduating. Washington, DC: Complete College America.

Deming, D.J., \& Walters, C.R. (2017). The impacts of price and spending subsidies on U.S. postsecondary $\begin{array}{llll}\text { attainment. } & \text { Working } & \text { paperieved }\end{array}$ http://scholar.harvard.edu/files/ddeming/files/demingwalters_higheredspending_jan2017.pdf

DesJardins, Stephen L., Dennis A. Ahlburg, and Brian P. McCall (2006). The effects of interrupted enrollmenr on graduation from college: Racial, income, and ability differences. Economics of Education Review 25: 575-590.

Druesne, B. (1982). What 200 studies reveal about CLEP. New York: College Board.

Dynarski, S. (2002). The behavioral and distributional implications of aid for college. American Economic Review, 92(2), 279-285.

Dynarski, S. (2008). Building the stock of college-educated labor. Journal of Human Resources, 43(3), 576610.

Dynarski, S. (2015). "How to Improve Graduation Rates at Community Colleges," New York Times - The Upshot, March, 11, 2015.

Dynarski, S., Hemelt, S., \& Hyman, J. (2015). The missing manual: Usign National Student Clearinghouse data to track postsecondary outcomes. Education Evaluation and Policy Analysis, 37(1), 53-79.

Hayward, M. S., \& Williams, M. R. (2015). Adult learner graduation rates at four US community colleges by prior learning assessment status and method. Community College Journal of Research and Practice, 39(1), 44-54.

Imbens, G., \& Kalyanaraman, K. (2012). Optimal bandwidth choice for the regression discontinuity estimator. The Review of Economic Studies, 79(3), 933-959.

Johnson, J. J., \& Knight, K. H. (1987). College level examination program scores as predictors of grade point average. Educational and Psychological Measurement, 47(4), 1031-1036.

Kane, T. J. (2003). A quasi-experimental estimate of the impact of financial aid on college-going (No. w9703). National Bureau of Economic Research.

Klein-Collins, R. (2010). Fueling the race to postsecondary success: A 48-institution study of prior learning assessment and adult student outcomes. Washington, DC: Council for Adult and Experiential Learning and Lumina Foundation. 
Klein-Collins, R., \& Wertheim, J. B. (2013). Growing Importance of Prior Learning Assessment in the Degree-Completion Toolkit. New Directions for Adult and Continuing Education, 2013(140), 5160.

Lakin, M. B., Seymour, D., Nellum, C. J., \& Crandall, J. R. (2015). Credit for Prior Learning. Washington, D.C.: American Council on Education. Retrieved from: http://www.acenet.edu/newsroom/Documents/Credit-for-Prior-Learning-Charting-Institutional-Practice-for-Sustainability.pdf.

Markle, G. (2015). Factors influencing persistence among nontraditional university students. Adult Education Quarterly, doi: 0741713615583085.

O'Toole, D. M., Stratton, L. S., \& Wetzel, J. N. (2003). A longitudinal analysis of the frequency of part-time enrollment and the persistence of students who enroll part time. Research in Higher Education, 44(5), 519-537.

Papay, J., E. Murnane, and J. Willett (2017). "The Impact of Test Score Labels on Human-Capital Investment Decisions," Journal of Human Resources, 52(1): 357-388.

Pearson, W. (2000). Enhancing adult student persistence: The relationship between prior learning assessment and persistence toward the baccalaureate degree. lowa State University. Retrieved from http://ldms.oum.edu.my/oumlib/sites/default/files/file attachments/odlresources/4463/enhancing-adult-student.pdf

Scammacca, N.K. (2003). An Integrative, pragmatic approach to evaluation: The College-Level Examination Program. Dissertation: University of Texas at Austin. Retrieved from: https://www.lib.utexas.edu/etd/d/2003/scammaccank039/scammaccank039.pdf

Scott-Clayton, J. (2011). On money and motivation: a quasi-experimental analysis of financial incentives for college achievement. Journal of Human Resources, 46(3), 614-646.

Scrivener, S., Weiss, M. J., Ratledge, A., Rudd, T., Sommo, C., \& Fresques, H. (2015). Doubling Graduation Rates: Three-Year Effects of CUNY's Accelerated Study in Associate Programs (ASAP) for Developmental Education Students. New York: MDRC.

Seftor, N. S., Mamun, A., \& Schirm, A. (2009). The Impacts of Regular Upward Bound on Postsecondary Outcomes Seven to Nine Years after Scheduled High School Graduation. Final Report. U.S. Department of Education.

Shapiro, D., Dundar, A., Yuan, X., Harrell, A., Wild, J., Ziskin, M. (2014). Some college, no degree: A national view of students with some college enrollment, but no completion (Signature Report No. 7). Herndon, VA: National Student Clearinghouse Research Center. 
Sharon, A. (1970). Measurement of College Achievement by the College-Level Examination Program. Princeton, NJ.

Speroni, C. (2011). High School Dual Enrollment Programs: Are We Fast-Tracking Students Too Fast? An NCPR Working Paper. National Center for Postsecondary Research.

Smith, J., Hurwitz, M., \& Avery, C. (2017). Giving college credit where it is due: Advanced Placement exam scores and college outcomes. Journal of Labor Economics, 35(1): 67-147.

Struhl, B., \& Vargas, J. (2012). Taking college courses in high school: A strategy for college readiness: The college outcomes of dual enrollment in texas. Boston: Jobs for the Future.

Taniguchi, H., \& Kaufman, G. (2005). Degree completion among nontraditional college students. Social Science Quarterly, 86(4), 912-927.

Titus, M. A. (2006). Understanding college degree completion of students with low socioeconomic status: The influence of the institutional financial context. Research in Higher Education, 47(4), 371-398.

Turner, S. (2004). Going to college and finishing college. Explaining different educational outcomes. In College choices: The economics of where to go, when to go, and how to pay for it (pp. 13-62). Chicago, IL: University of Chicago Press.

U.S. Department of Education (2016). National Center for Education Statistics. The Condition of Education 2016 (NCES 2016-144), Undergraduate Retention and Graduation Rates.

U.S. Department of Education. (2015). Federal TRIO Programs, Funding Status, https://www2.ed.gov/programs/trioupbound/funding.html

U.S. Department of Education. (2014). National Center for Education Statistics. Integrated Postsecondary Education Data System (IPEDS), Fall 2001 and Spring 2002 through Spring 2014 Graduation Rates component. Retrieved from: http://nces.ed.gov/programs/digest/d14/tables/dt14_326.20.asp

Weiss, M. J., Mayer, A. K., Cullinan, D., Ratledge, A., Sommo, C., \& Diamond, J. (2015). A random assignment evaluation of learning communities at Kingsborough Community College-Seven years later. Journal of Research on Educational Effectiveness, 8(2), 189-217. 
Table 1: Summary Statistics

\begin{tabular}{|c|c|c|c|}
\hline & Obs. & Mean & Std. Dev. \\
\hline \multicolumn{4}{|l|}{ Background Variables } \\
\hline Asian & 811,103 & 0.045 & 0.207 \\
\hline Black & 811,103 & 0.093 & 0.291 \\
\hline Hispanic & 811,103 & 0.244 & 0.430 \\
\hline White & 811,103 & 0.554 & 0.497 \\
\hline Other & 811,103 & 0.055 & 0.229 \\
\hline Missing Race & 811,103 & 0.008 & 0.091 \\
\hline Female & 811,103 & 0.502 & 0.500 \\
\hline Age & 811,103 & 26.488 & 9.205 \\
\hline Military Member & 811,103 & 0.249 & 0.432 \\
\hline Home Schooled & 811,103 & 0.035 & 0.183 \\
\hline \multicolumn{4}{|l|}{ CLEP Variables } \\
\hline Number of CLEP Exams & 811,103 & 1.579 & 1.456 \\
\hline First CLEP Score & 811,103 & 57.139 & 12.810 \\
\hline Average of All CLEP Scores & 811,103 & 56.865 & 12.377 \\
\hline Took First CLEP Before Enrolling & 811,103 & 0.257 & 0.437 \\
\hline Enrolled in Two-Year College After/While Taking CLEP & 811,103 & 0.216 & 0.412 \\
\hline Enrolled in Four-Year College After/While Taking CLEP & 811,103 & 0.678 & 0.467 \\
\hline \multicolumn{4}{|l|}{ Forcing Variables } \\
\hline (1) Distance Between CLEP Score and 50 & 811,103 & 7.139 & 12.810 \\
\hline (2) Distance Between CLEP Score and Minimum Credit Granting Score at First College Enrolled & 636,043 & 7.461 & 13.363 \\
\hline (3) Distance Between CLEP Score and Minimum Credit Granting Score at Testing Center & 652,850 & 8.075 & 13.380 \\
\hline Forcing Variable (1) Greater Than or Equal to Zero & 811,103 & 0.709 & 0.454 \\
\hline Forcing Variable (2) Greater Than or Equal to Zero & 636,043 & 0.708 & 0.455 \\
\hline Forcing Variable (3) Greater Than or Equal to Zero & 652,850 & 0.723 & 0.447 \\
\hline \multicolumn{4}{|l|}{ Outcome Variables } \\
\hline Any Degree & 811,103 & 0.518 & 0.500 \\
\hline Bachelor's Degree & 811,103 & 0.370 & 0.483 \\
\hline Associate's Degree & 811,103 & 0.196 & 0.397 \\
\hline Associate's Degree or Certificate & 811,103 & 0.206 & 0.404 \\
\hline Time to Bachelor's Degree (Years) from first CLEP & 299,929 & 3.882 & 2.136 \\
\hline Time to Associate's Degree (Years) from first CLEP & 159,381 & 3.161 & 2.435 \\
\hline Majored in Same Subject as CLEP Exam & 811,103 & 0.029 & 0.167 \\
\hline
\end{tabular}


Table 2: Covariate Balancing and Density Tests

\begin{tabular}{|c|c|c|c|}
\hline & $\begin{array}{c}\text { Forcing } \\
\text { Variable (1) - } \\
\text { Distance } \\
\text { From } 50\end{array}$ & $\begin{array}{c}\text { Forcing Variable (2) - } \\
\text { Distance From Credit } \\
\text { Granting Score at } \\
\text { Testing Center } \\
\text { College }\end{array}$ & $\begin{array}{c}\text { Forcing Variable (3) - } \\
\text { Distance From Credit } \\
\text { Granting Score at First } \\
\text { College Enrolled }\end{array}$ \\
\hline $\begin{array}{l}\text { Density } \\
\text { Above Threshold }\end{array}$ & $\begin{array}{l}-0.008 \\
(0.009)\end{array}$ & $\begin{array}{l}-0.008 \\
(0.011) \\
\end{array}$ & $\begin{array}{l}-0.008 \\
(0.011) \\
\end{array}$ \\
\hline \multicolumn{4}{|l|}{ Covariates } \\
\hline Asian & $\begin{array}{l}-0.001 \\
(0.002)\end{array}$ & $\begin{array}{l}-0.001 \\
(0.002)\end{array}$ & $\begin{array}{l}-0.003 \\
(0.002)\end{array}$ \\
\hline Black & $\begin{array}{l}-0.002 \\
(0.003)\end{array}$ & $\begin{array}{l}-0.001 \\
(0.003)\end{array}$ & $\begin{array}{l}-0.004 \\
(0.003)\end{array}$ \\
\hline Hispanic & $\begin{array}{l}-0.003 \\
(0.002)\end{array}$ & $\begin{array}{c}0.001 \\
(0.003)\end{array}$ & $\begin{array}{l}-0.003 \\
(0.003)\end{array}$ \\
\hline White & $\begin{array}{c}0.011^{* * *} \\
(0.004)\end{array}$ & $\begin{array}{c}0.007 \\
(0.005)\end{array}$ & $\begin{array}{c}0.016 * * * \\
(0.005)\end{array}$ \\
\hline Other & $\begin{array}{c}-0.006^{* * *} \\
(0.002)\end{array}$ & $\begin{array}{c}-0.007^{* * *} \\
(0.002)\end{array}$ & $\begin{array}{c}-0.007^{* * *} \\
(0.002)\end{array}$ \\
\hline Missing Race & $\begin{array}{c}0.001 \\
(0.001)\end{array}$ & $\begin{array}{c}0.001 \\
(0.001)\end{array}$ & $\begin{array}{c}0.001 \\
(0.001)\end{array}$ \\
\hline Female & $\begin{array}{l}-0.001 \\
(0.004)\end{array}$ & $\begin{array}{l}-0.005 \\
(0.005)\end{array}$ & $\begin{array}{l}-0.000 \\
(0.005)\end{array}$ \\
\hline Age & $\begin{array}{l}-0.125 \\
(0.082)\end{array}$ & $\begin{array}{l}-0.115 \\
(0.093)\end{array}$ & $\begin{array}{l}-0.133 \\
(0.091)\end{array}$ \\
\hline Military Member & $\begin{array}{l}-0.001 \\
(0.004)\end{array}$ & $\begin{array}{c}0.002 \\
(0.004)\end{array}$ & $\begin{array}{c}0.002 \\
(0.004)\end{array}$ \\
\hline Home Schooled & $\begin{array}{l}0.003^{* *} \\
(0.001)\end{array}$ & $\begin{array}{l}0.003 * * \\
(0.002)\end{array}$ & $\begin{array}{c}0.002 \\
(0.002)\end{array}$ \\
\hline Currently in High School & $\begin{array}{l}-0.001 \\
(0.003)\end{array}$ & $\begin{array}{l}-0.002 \\
(0.003)\end{array}$ & $\begin{array}{c}0.002 \\
(0.003)\end{array}$ \\
\hline High School Graduate & $\begin{array}{l}-0.005 \\
(0.003)\end{array}$ & $\begin{array}{l}-0.002 \\
(0.004)\end{array}$ & $\begin{array}{l}-0.003 \\
(0.003)\end{array}$ \\
\hline Enrolled in College & $\begin{array}{c}0.000 \\
(0.004)\end{array}$ & $\begin{array}{l}-0.002 \\
(0.005)\end{array}$ & $\begin{array}{l}-0.001 \\
(0.005)\end{array}$ \\
\hline College Graduate & $\begin{array}{c}0.003 \\
(0.002)\end{array}$ & $\begin{array}{l}0.006 * * \\
(0.003)\end{array}$ & $\begin{array}{l}-0.001 \\
(0.002)\end{array}$ \\
\hline $\begin{array}{l}\text { Predicted CLEP Score } \\
\text { Observations }\end{array}$ & $\begin{array}{l}-0.020 \\
(0.045) \\
278,844\end{array}$ & $\begin{array}{c}0.030 \\
(0.048) \\
215,600\end{array}$ & $\begin{array}{l}-0.039 \\
(0.051) \\
214,869\end{array}$ \\
\hline \multicolumn{4}{|c|}{$\begin{array}{l}\left.\text { Notes: Heteroskedasticity robust standard errors are in parentheses ( }{ }^{*} p<.10 * * p<.05 * * * p<.01\right) \text {. Each } \\
\text { estimate comes from a local linear regression of the covariates on the forcing variables indicated by } \\
\text { the column headers, an indicator variable for whether the forcing variable is greater than or equal to } 0 \\
\text { (i.e. eligible for credit) and the interaction of these two terms. We use a bandwidth of } 7 \text { with } \\
\text { triangular kernels. The discontinuties in density come from formal McCrary tests and represent the } \\
\text { log difference in height. We obtain predicted CLEP scores from regressing all covariates listed in this } \\
\text { table on the student's CLEP score. }\end{array}$} \\
\hline
\end{tabular}


Table 3: Impact of Receiving CLEP Credit on Degree Attainment

\begin{tabular}{|c|c|c|c|c|c|}
\hline \multicolumn{3}{|c|}{ OLS } & \multicolumn{3}{|c|}{ Reduced Form Estimates } \\
\hline & & Four- & & & \\
\hline$\underline{\text { All }}$ & Two-Year & Year & $\underline{A l l}$ & Two-Year & Four-Year \\
\hline Students & $\underline{\text { Students }}$ & Students & $\underline{\text { Students }}$ & $\underline{\text { Students }}$ & $\underline{\text { Students }}$ \\
\hline
\end{tabular}

$\begin{array}{lllll}\text { (1) (2) (3) (4) } & \text { (4) }\end{array}$

Above Threshold/ Total Exams

Passed

Panel A: Any Degree

\begin{tabular}{|c|c|c|c|c|c|c|}
\hline Passed & $\begin{array}{c}0.030 * * * \\
(0.001)\end{array}$ & $\begin{array}{c}0.035^{* * *} \\
(0.002)\end{array}$ & $\begin{array}{c}0.027^{* * *} \\
(0.001)\end{array}$ & $\begin{array}{c}0.030 * * * \\
(0.005)\end{array}$ & $\begin{array}{c}0.034^{* * *} \\
(0.009)\end{array}$ & $\begin{array}{c}0.029 * * * \\
(0.005)\end{array}$ \\
\hline Observations & 243,845 & 63,186 & 195,865 & 243,845 & 63,186 & 195,865 \\
\hline $\begin{array}{l}\text { Optimal Bandwidth } \\
\text { Control Mean }\end{array}$ & & & & $\begin{array}{l}7.174 \\
0.562\end{array}$ & $\begin{array}{c}10.180 \\
0.485\end{array}$ & $\begin{array}{l}7.641 \\
0.582\end{array}$ \\
\hline & \multicolumn{6}{|c|}{ Panel B: Associate's Degree } \\
\hline \multicolumn{7}{|l|}{ Above Threshold/ Total Exams } \\
\hline Passed & $\begin{array}{c}0.021 * * * \\
(0.001)\end{array}$ & $\begin{array}{c}0.029 * * * \\
(0.002)\end{array}$ & $\begin{array}{c}0.017^{* * * *} \\
(0.001)\end{array}$ & $\begin{array}{c}0.030 * * * \\
(0.004)\end{array}$ & $\begin{array}{c}0.057 * * * \\
(0.008)\end{array}$ & $\begin{array}{c}0.021^{* * *} \\
(0.004)\end{array}$ \\
\hline Observations & 214,869 & 67,840 & 217,605 & 214,869 & 67,840 & 217,605 \\
\hline $\begin{array}{l}\text { Optimal Bandwidth } \\
\text { Control Mean }\end{array}$ & & & & $\begin{array}{l}6.940 \\
0.197\end{array}$ & $\begin{array}{c}11.086 \\
0.329\end{array}$ & $\begin{array}{l}8.934 \\
0.163\end{array}$ \\
\hline & \multicolumn{6}{|c|}{ Panel C: Bachelor's Degree } \\
\hline Above Threshold/ Total Exams & & & & & & \\
\hline Passed & $\begin{array}{c}0.021^{* * *} \\
(0.001)\end{array}$ & $\begin{array}{c}0.009 * * * \\
(0.002)\end{array}$ & $\begin{array}{c}0.018^{* * *} \\
(0.001)\end{array}$ & $\begin{array}{c}0.005 \\
(0.003)\end{array}$ & $\begin{array}{c}-0.016^{* *} \\
(0.008)\end{array}$ & $\begin{array}{c}0.012^{* * *} \\
(0.004)\end{array}$ \\
\hline Observations & 365,599 & 53,232 & 276,034 & 365,599 & 53,232 & 276,034 \\
\hline $\begin{array}{l}\text { Optimal Bandwidth } \\
\text { Control Mean }\end{array}$ & & & & $\begin{array}{c}12.935 \\
0.407\end{array}$ & $\begin{array}{l}8.509 \\
0.203\end{array}$ & $\begin{array}{c}11.848 \\
0.459\end{array}$ \\
\hline
\end{tabular}

Notes: Heteroskedasticity robust standard errors are in parentheses $(* p<.10 * * p<.05 * * * p<.01)$. In the first three columns, we show the endogenous parameter estimates by simply regressing the completion outcome on the number of CLEP exams passed. In columns 4 through 6 , we regress the completion outcome on an indicator variable for whether a student's first CLEP score met or exceeded the relevant subjectspecific CLEP credit-granting threshold at the student's first institution, the distance between the student's CLEP score and the credit-granting threshold (the forcing variable), and an interaction of these two variables. Control means represent the averages 1 point below the cut score at the enrolling institution. We use triangular kernels in the regression discontinuity models. 
Table 4: Impact of Receiving CLEP Credit on Time-to-Degree

\begin{tabular}{|c|c|c|c|c|c|c|}
\hline & \multicolumn{6}{|c|}{ Time to Degree in Days } \\
\hline & $\frac{\frac{\text { Between CLEP }}{\frac{\text { Date and }}{\text { Associates }}}}{\frac{\text { Degree }}{(1)}}$ & $\frac{\frac{\text { Between CLEP }}{\frac{\text { Date and }}{\text { Bachelors }}}}{\frac{\text { Degree }}{(2)}}$ & $\frac{\frac{\text { Between Initial }}{\text { Enrollment and }}}{\frac{\text { Associates }}{\frac{\text { Degree }}{(1)}}}$ & $\frac{\frac{\text { Between Initial }}{\text { Enrollment and }}}{\frac{\text { Bachelors }}{\frac{\text { Degree }}{(2)}}}$ & $\frac{\frac{\text { Associates }}{\text { Degree }}}{\frac{\text { Within } 3}{\text { Years }}}$ & $\frac{\frac{\text { Bachelors }}{\text { Degree }}}{\frac{\text { Within 6 }}{\underline{\text { Years }}}}$ \\
\hline & \multicolumn{6}{|c|}{ Panel 1: All Students } \\
\hline Above Threshold & $\begin{array}{c}-79.266 * * * \\
(10.297)\end{array}$ & $\begin{array}{c}-27.862 * * * \\
(8.401)\end{array}$ & $\begin{array}{c}-53.927^{* * *} \\
(13.803)\end{array}$ & $\begin{array}{c}-21.870^{* *} \\
(9.839)\end{array}$ & $\begin{array}{c}0.022^{* * *} \\
(0.003)\end{array}$ & $\begin{array}{c}0.006 \\
(0.004)\end{array}$ \\
\hline Observations & 66,014 & 113,419 & 75,164 & 113,419 & 270,837 & 343,874 \\
\hline Optimal Bandwidth & 10.342 & 8.138 & 12.728 & 8.823 & 8.805 & 11.041 \\
\hline Control Mean & 758.884 & 687.961 & $1,121.102$ & $1,408.261$ & 0.125 & 0.363 \\
\hline & \multicolumn{6}{|c|}{ Panel 2: Started at two-year College } \\
\hline Above Threshold & $\begin{array}{c}-96.108^{* * *} \\
(17.688)\end{array}$ & $\begin{array}{c}29.813 \\
(23.454)\end{array}$ & $\begin{array}{c}-81.159 * * * \\
(28.964)\end{array}$ & $\begin{array}{c}55.991 \\
(37.933)\end{array}$ & $\begin{array}{c}0.035^{* * *} \\
(0.006)\end{array}$ & $\begin{array}{c}-0.021 * * * \\
(0.008)\end{array}$ \\
\hline Observations & 21,035 & 14,246 & 22,824 & 11,437 & 83,789 & 47,980 \\
\hline Optimal Bandwidth & 9.610 & 12.613 & 10.825 & 9.850 & 15.126 & 7.315 \\
\hline Control Mean & 743.306 & 1,047.199 & $1,346.414$ & $1,556.302$ & 0.185 & 0.170 \\
\hline & \multicolumn{6}{|c|}{ Panel 3: Started at four-year college } \\
\hline Above Threshold & $\begin{array}{c}-75.970 * * * \\
(11.824)\end{array}$ & $\begin{array}{c}-29.229 * * * \\
(8.762)\end{array}$ & $\begin{array}{c}-54.814^{* * *} \\
(16.968)\end{array}$ & $\begin{array}{c}-28.198 * * * \\
(9.527)\end{array}$ & $\begin{array}{c}0.018^{* * *} \\
(0.003)\end{array}$ & $\begin{array}{c}0.013 * * * \\
(0.004)\end{array}$ \\
\hline Observations & 48,912 & 92,690 & 43,190 & 113,345 & 217,605 & 238,408 \\
\hline Optimal Bandwidth & 12.333 & 7.806 & 10.519 & 9.621 & 8.867 & 9.325 \\
\hline Control Mean & 766.838 & 647.552 & $1,006.052$ & $1,391.608$ & 0.109 & 0.412 \\
\hline
\end{tabular}

Notes: Heteroskedasticity robust standard errors are in parentheses ( $* p<.10 * * p<.05 * * * p<.01)$. Each estimate comes from a local linear regression with a triangular kernel of the outcomes regressed on a forcing variable representing the distance between the student's first CLEP score and minimum credit-granting threshold, an indicator variable for whether the forcing variable is greater than or equal to 0 (i.e. eligible for credit) and interaction of these two terms. 
Table 5: Impact of Receiving CLEP Credit on CLEP Retaking/Additional CLEP Test-Taking

\begin{tabular}{|c|c|c|c|c|}
\hline \multirow[b]{2}{*}{ Forcing Variable } & $\frac{\text { Retook First }}{\text { CLEP }}$ & $\frac{\text { Took Subsequent }}{\text { (Different) Exam }}$ & $\frac{\text { Total Subsequent }}{\text { (Different Exams) }}$ & $\frac{\frac{\text { Total Credit-Granting }}{\text { CLEP Scores }}}{\text { CLE }}$ \\
\hline & \multicolumn{4}{|c|}{ Distance from College-Specific Minimum Credit-Granting Threshold } \\
\hline \multirow[t]{2}{*}{ Above Threshold } & $-0.091 * * *$ & $0.030 * * *$ & $0.091^{* * *}$ & $0.958^{* * *}$ \\
\hline & $(0.003)$ & $(0.004)$ & $(0.010)$ & (0.009) \\
\hline Observations & 177,637 & 286,742 & 309,906 & 177,637 \\
\hline Optimal Bandwidth & 5.043 & 9.349 & 10.112 & 5.958 \\
\hline Control Mean & 0.092 & 0.267 & 0.502 & 0.316 \\
\hline
\end{tabular}

Notes: Heteroskedasticity robust standard errors are in parentheses $(* p<.10 * * p<.05 * * * p<.01)$. Each estimate comes from a local linear regression with a triangular kernel of the outcomes regressed on the specified forcing variable, an indicator variable for whether the forcing variable is greater than or equal to 0 and an interaction of these two terms. The first three columns exclude students who took more than one exam during first exam day. 
Table 6: Effect of Receiving Credit on the 2nd Exam for those Students Who Passed/Failed the First Exam

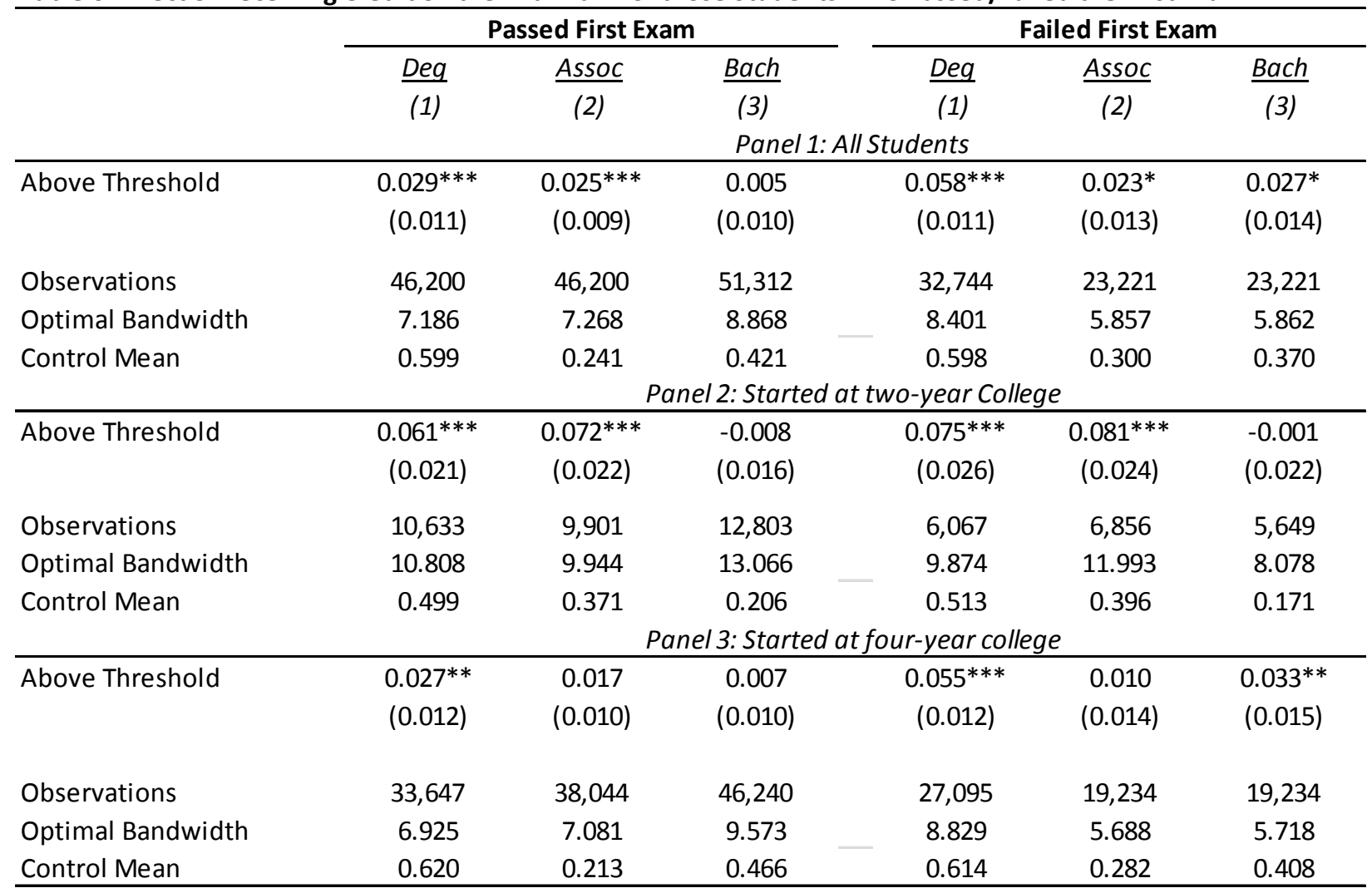

Notes: Heteroskedasticity robust standard errors are in parentheses $\left(* p<.10^{* *} p<.05^{* * *} p<.01\right)$. Each estimate comes from a local linear regression with a triangular kernel of the outcomes regressed on a forcing variable representing the distance between the student's first CLEP score and minimum credit-granting threshold, an indicator variable for whether the forcing variable is greater than or equal to 0 (i.e. eligible for credit) and interaction of these two terms. Excludes cases where the first and second exams were in the same subject and students received credit-granting scores on both. 
Table 7: Impact of Receiving CLEP Credit on Degree Enrollment

\begin{tabular}{|c|c|c|c|c|c|}
\hline \multicolumn{3}{|c|}{ College } & \multicolumn{3}{|c|}{ All Potential College Enrollees } \\
\hline & First & & & & \\
\hline & Enrolled & First Enrolled & & First Enrolled & First \\
\hline Enrolled & in $2-Y r$ & in $4-Y r$ & Enrolled in & in $2-Y_{r}$ & Enrolled in 4- \\
\hline in College & College & College & College & College & Yr College \\
\hline
\end{tabular}

(1)

(2)

(3)

(4)

(5)

(6)

Above Threshold

Forcing Variable (1) - Distance From 50

\begin{tabular}{cccccc}
\hline 0.003 & -0.002 & 0.004 & 0.001 & $-0.007^{* *}$ & $0.008^{* *}$ \\
$(0.007)$ & $(0.005)$ & $(0.007)$ & $(0.003)$ & $(0.003)$ & $(0.004)$ \\
89,522 & 108,224 & 99,091 & 278,844 & 316,460 & 316,460 \\
7.980 & 9.535 & 8.056 & 6.984 & 7.181 & 7.322 \\
0.605 & 0.162 & 0.443 & 0.888 & 0.209 & 0.679 \\
Forcing & Variable (2) & Distance From & Credit Granting & Score at Testing Center \\
\hline \multicolumn{7}{c}{0.000} & -0.001 & -0.000 & -0.000 & -0.003 & 0.003 \\
$(0.008)$ & $(0.005)$ & $(0.008)$ & $(0.003)$ & $(0.003)$ & $(0.004)$ \\
76,237 & 93,047 & 69,806 & 272,195 & 272,195 & 272,195 \\
9.116 & 12.875 & 8.381 & 8.189 & 8.687 & 8.171 \\
0.604 & 0.162 & 0.442 & 0.897 & 0.204 & 0.693 \\
\hline
\end{tabular}

Observations

Optimal Bandwidth

Control Mean

Above Threshold

observations

Optimal Bandwidth

Control Mean

$0.604 \quad 0.162$

0.442

0.897

0.204

0.693

Notes: Heteroskedasticity robust standard errors are in parentheses $\left({ }^{*} p<.10 * * p<.05 * * * p<.01\right)$. Each estimate comes from a local linear regression with a triangular kernel of the outcomes on the forcing variables indicated by the column headers, an indicator variable for whether the forcing variable is greater than or equal to 0 (i.e. eligible for credit) and interaction of these two terms. 
Table 8: Impact of Receiving CLEP Credit on Degree Attainment by Length of Enrollment

\begin{tabular}{|c|c|c|c|c|c|c|}
\hline \multirow{3}{*}{ Above Threshold } & $\frac{0-180}{\underline{\text { days }}}$ & $\frac{180-365}{\underline{\text { days }}}$ & $\frac{1-2}{\text { years }}$ & $\frac{2-3}{\text { years }}$ & $\frac{3-4}{\text { years }}$ & $\frac{\geq 4}{\text { years }}$ \\
\hline & \multicolumn{6}{|c|}{ Outcome $=$ Any Degree } \\
\hline & $\begin{array}{l}0.028 * * \\
(0.012)\end{array}$ & $\begin{array}{c}0.035^{* * * *} \\
(0.010)\end{array}$ & $\begin{array}{c}0.022^{* * *} \\
(0.008)\end{array}$ & $\begin{array}{c}0.040 * * * \\
(0.009)\end{array}$ & $\begin{array}{c}0.039 * * * \\
(0.011)\end{array}$ & $\begin{array}{c}0.014 \\
(0.014)\end{array}$ \\
\hline Observations & 37,015 & 44,023 & 70,498 & 47,153 & 33,658 & 21,133 \\
\hline \multirow[t]{2}{*}{ Control Mean } & $\begin{array}{l}6.110 \\
0.488\end{array}$ & $\begin{array}{l}9.465 \\
0.524\end{array}$ & $\begin{array}{c}12.241 \\
0.624\end{array}$ & $\begin{array}{l}9.693 \\
0.708\end{array}$ & $\begin{array}{l}12.666 \\
0.714\end{array}$ & $\begin{array}{c}12.605 \\
0.654\end{array}$ \\
\hline & \multicolumn{6}{|c|}{ Outcome $=$ Bachelor's Degree, Conditional on Starting at } \\
\hline Above Threshold & $\begin{array}{c}0.004 \\
(0.010)\end{array}$ & $\begin{array}{c}0.013 \\
(0.010)\end{array}$ & $\begin{array}{l}0.018^{*} \\
(0.011)\end{array}$ & $\begin{array}{l}0.022 * * \\
(0.009)\end{array}$ & $\begin{array}{l}0.025^{* *} \\
(0.010)\end{array}$ & $\begin{array}{l}-0.004 \\
(0.014)\end{array}$ \\
\hline Observations & 38,988 & 38,492 & 45,026 & 50,308 & 35,223 & 19,450 \\
\hline \multirow[t]{2}{*}{$\begin{array}{l}\text { Optimal Bandwidth } \\
\text { Control Mean }\end{array}$} & $\begin{array}{l}9.955 \\
0.312\end{array}$ & $\begin{array}{c}11.544 \\
0.335\end{array}$ & $\begin{array}{l}9.045 \\
0.499\end{array}$ & $\begin{array}{c}12.877 \\
0.661\end{array}$ & $\begin{array}{l}16.892 \\
0.703\end{array}$ & $\begin{array}{c}13.751 \\
0.645\end{array}$ \\
\hline & \multicolumn{6}{|c|}{$\begin{array}{c}\text { Outcome }=\text { Associate's Degree, Conditional on Starting at } \\
\text { Two-Year College }\end{array}$} \\
\hline Above Threshold & $\begin{array}{l}0.063^{* * *} \\
(0.019)\end{array}$ & $\begin{array}{l}0.075 * * * \\
(0.022)\end{array}$ & $\begin{array}{l}0.051^{* * *} \\
(0.018)\end{array}$ & $\begin{array}{l}0.104^{* * *} \\
(0.024)\end{array}$ & $\begin{array}{l}0.071^{* * *} \\
(0.027)\end{array}$ & $\begin{array}{l}0.082 * * \\
(0.039)\end{array}$ \\
\hline Observations & 11,801 & 9,807 & 13,695 & 7,647 & 5,165 & 2,321 \\
\hline $\begin{array}{l}\text { Optimal Bandwidth } \\
\text { Control Mean }\end{array}$ & $\begin{array}{l}9.386 \\
0.345 \\
\end{array}$ & $\begin{array}{l}8.382 \\
0.364 \\
\end{array}$ & $\begin{array}{c}11.871 \\
0.380 \\
\end{array}$ & $\begin{array}{c}11.729 \\
0.399 \\
\end{array}$ & $\begin{array}{c}15.250 \\
0.299 \\
\end{array}$ & $\begin{array}{c}10.002 \\
0.206 \\
\end{array}$ \\
\hline \multicolumn{7}{|c|}{$\begin{array}{l}\text { Notes: Heteroskedasticity robust standard errors are in parentheses }(* p<.10 * * p<.05 * * * \\
p<.01) \text {. Each estimate comes from a local linear regression of the covariates on the forcing } \\
\text { variable- distance from credit granting score at first college enrolled, an indicator variable for } \\
\text { whether the forcing variable is greater than or equal to } 0 \text { (i.e. eligible for credit) and } \\
\text { interaction of these two terms. }\end{array}$} \\
\hline
\end{tabular}


Table 9: Heterogeneous Impact of Receiving CLEP Credit on Degree Attainment

\begin{tabular}{|c|c|c|c|c|c|c|c|c|c|c|}
\hline & $\frac{\frac{\text { Military }}{\text { Member }}}{(1)}$ & $\frac{\frac{\text { Home }}{\text { Schooled }}}{(2)}$ & $\frac{\text { White }}{\text { (3) }}$ & $\begin{array}{l}\frac{\text { Asian }}{(4)} \\
\text { Outco }\end{array}$ & $\begin{array}{c}\frac{\text { Black }}{(5)} \\
m e=A n y\end{array}$ & $\begin{array}{l}\frac{\text { Hispanic }}{(6)} \\
\text { Degree }\end{array}$ & $\frac{\text { Male }}{\text { (7) }}$ & $\frac{\text { Female }}{\text { (8) }}$ & $\frac{\text { Age }<25}{\text { (9) }}$ & $\frac{\text { Age }>=}{\frac{25}{(10)}}$ \\
\hline Above Threshold & $\begin{array}{c}0.064^{* * *} \\
(0.007)\end{array}$ & $\begin{array}{l}0.049 * * \\
(0.022)\end{array}$ & $\begin{array}{c}0.022^{* * *} \\
(0.006)\end{array}$ & $\begin{array}{c}0.029 \\
(0.019)\end{array}$ & $\begin{array}{c}0.039 * * * \\
(0.011)\end{array}$ & $\begin{array}{c}0.053^{* * *} \\
(0.011)\end{array}$ & $\begin{array}{c}0.041^{* * *} \\
(0.006)\end{array}$ & $\begin{array}{c}0.016^{* * *} \\
(0.005)\end{array}$ & $\begin{array}{c}0.022^{* * *} \\
(0.006)\end{array}$ & $\begin{array}{c}0.034^{* * *} \\
(0.005)\end{array}$ \\
\hline $\begin{array}{l}\text { Observations } \\
\text { Optimal Bandwidth } \\
\text { Control Mean }\end{array}$ & $\begin{array}{c}98,626 \\
11.387 \\
0.531\end{array}$ & $\begin{array}{c}10,078 \\
11.139 \\
0.285\end{array}$ & $\begin{array}{c}147,157 \\
6.110 \\
0.575\end{array}$ & $\begin{array}{c}12,905 \\
8.492 \\
0.529\end{array}$ & $\begin{array}{c}36,660 \\
11.353 \\
0.559\end{array}$ & $\begin{array}{c}38,247 \\
12.522 \\
0.548\end{array}$ & $\begin{array}{c}124,557 \\
7.996 \\
0.551\end{array}$ & $\begin{array}{c}166,821 \\
11.419 \\
0.574\end{array}$ & $\begin{array}{c}129,771 \\
7.459 \\
0.514\end{array}$ & $\begin{array}{c}144,127 \\
11.371 \\
0.619\end{array}$ \\
\hline & \multicolumn{10}{|c|}{ Outcome $=$ Bachelor's Degree, Conditional on Starting at Four-Year College } \\
\hline Above Threshold & $\begin{array}{c}0.026 * * * \\
(0.007)\end{array}$ & $\begin{array}{c}0.000 \\
(0.031)\end{array}$ & $\begin{array}{c}0.009 \\
(0.007)\end{array}$ & $\begin{array}{c}0.032 \\
(0.020)\end{array}$ & $\begin{array}{c}0.008 \\
(0.011)\end{array}$ & $\begin{array}{c}0.031 * * \\
(0.012)\end{array}$ & $\begin{array}{c}0.022 * * * \\
(0.006)\end{array}$ & $\begin{array}{c}0.008 \\
(0.007)\end{array}$ & $\begin{array}{c}0.006 \\
(0.006)\end{array}$ & $\begin{array}{c}0.026 * * * \\
(0.008)\end{array}$ \\
\hline $\begin{array}{l}\text { Observations } \\
\text { Optimal Bandwidth } \\
\text { Control Mean }\end{array}$ & $\begin{array}{c}72,412 \\
10.790 \\
0.235\end{array}$ & $\begin{array}{l}4,292 \\
7.869 \\
0.249\end{array}$ & $\begin{array}{c}118,603 \\
6.336 \\
0.478\end{array}$ & $\begin{array}{c}11,269 \\
9.542 \\
0.403\end{array}$ & $\begin{array}{c}31,269 \\
12.666 \\
0.435\end{array}$ & $\begin{array}{c}32,469 \\
13.726 \\
0.443\end{array}$ & $\begin{array}{c}131,018 \\
10.260 \\
0.404\end{array}$ & $\begin{array}{c}106,443 \\
8.135 \\
0.515\end{array}$ & $\begin{array}{c}116,237 \\
8.846 \\
0.451\end{array}$ & $\begin{array}{c}91,423 \\
8.083 \\
0.485\end{array}$ \\
\hline & \multicolumn{10}{|c|}{ Outcome $=$ Associate's Degree, Conditional on Starting at Two-Year College } \\
\hline Above Threshold & $\begin{array}{c}0.086 * * * \\
(0.015)\end{array}$ & $\begin{array}{c}0.091^{* * *} \\
(0.027)\end{array}$ & $\begin{array}{c}0.057^{* * *} \\
(0.011)\end{array}$ & $\begin{array}{c}0.104 * * * \\
(0.036)\end{array}$ & $\begin{array}{c}0.039 * \\
(0.023)\end{array}$ & $\begin{array}{c}0.050 * * * \\
(0.017)\end{array}$ & $\begin{array}{c}0.073 * * * \\
(0.012)\end{array}$ & $\begin{array}{c}0.039 * * * \\
(0.011)\end{array}$ & $\begin{array}{c}0.048 * * * \\
(0.011)\end{array}$ & $\begin{array}{c}0.073 * * * \\
(0.012)\end{array}$ \\
\hline Observations & 21,482 & 4,101 & 35,875 & 3,065 & 7,235 & 26,520 & 30,606 & 34,164 & 33,591 & 28,336 \\
\hline $\begin{array}{l}\text { Optimal Bandwidth } \\
\text { Control Mean }\end{array}$ & $\begin{array}{c}11.057 \\
0.474\end{array}$ & $\begin{array}{c}13.259 \\
0.145\end{array}$ & $\begin{array}{l}8.408 \\
0.338\end{array}$ & $\begin{array}{c}10.482 \\
0.267\end{array}$ & $\begin{array}{c}11.352 \\
0.332\end{array}$ & $\begin{array}{c}24.305 \\
0.307\end{array}$ & $\begin{array}{l}9.366 \\
0.365\end{array}$ & $\begin{array}{c}12.393 \\
0.288\end{array}$ & $\begin{array}{c}10.340 \\
0.278\end{array}$ & $\begin{array}{c}11.907 \\
0.374\end{array}$ \\
\hline
\end{tabular}

Notes: Heteroskedasticity robust standard errors are in parentheses $\left(* p<.10^{* *} p<.05^{* * *} p<.01\right)$. Each estimate comes from a local linear regression of the covariates on the forcing variable- distance from credit granting score at first college enrolled, an indicator variable for whether the forcing variable is greater than or equal to 0 (i.e. eligible for credit) and interaction of these two terms. 
Figure 1: College Completion, by Distance to College-Specific Credit Granting Thresholds
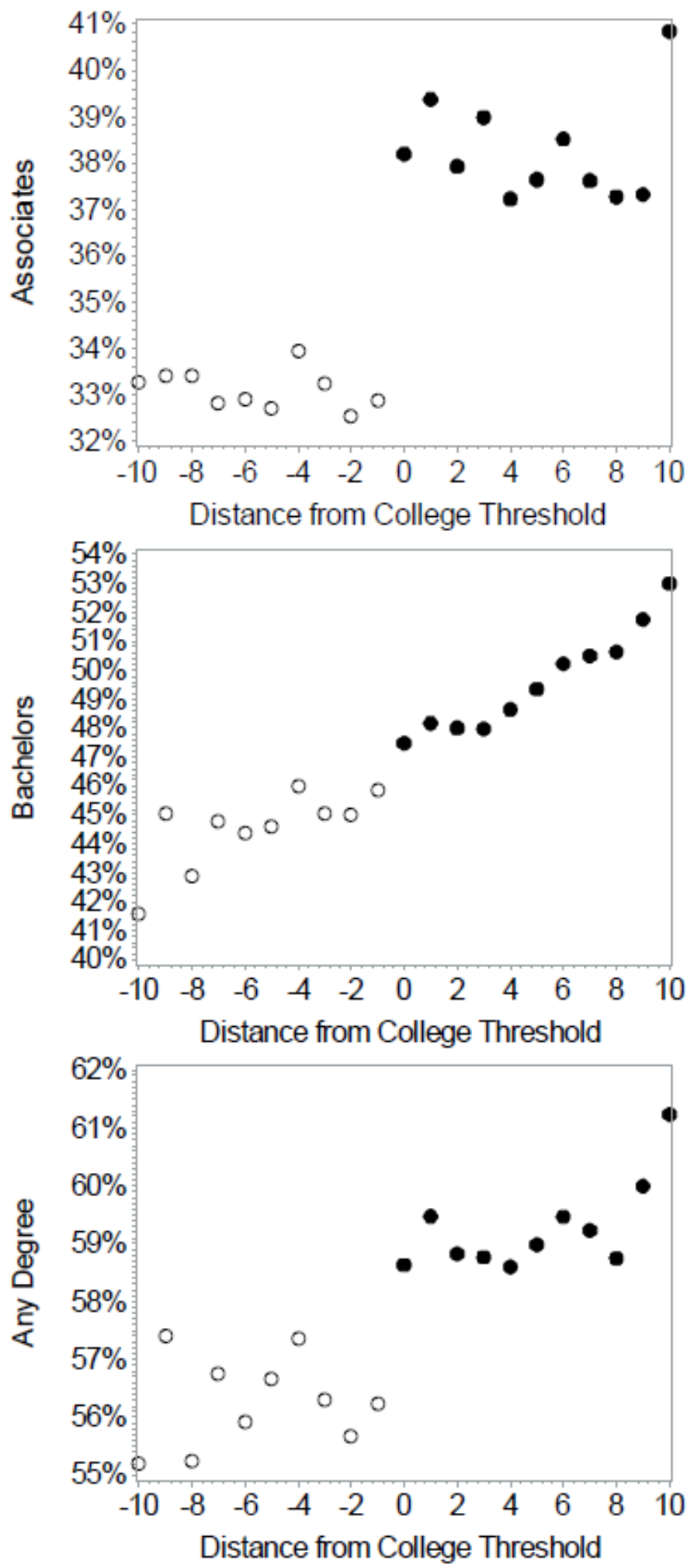
Figure 2: Density of Observations, by Distance to College-Specific Credit Granting Thresholds

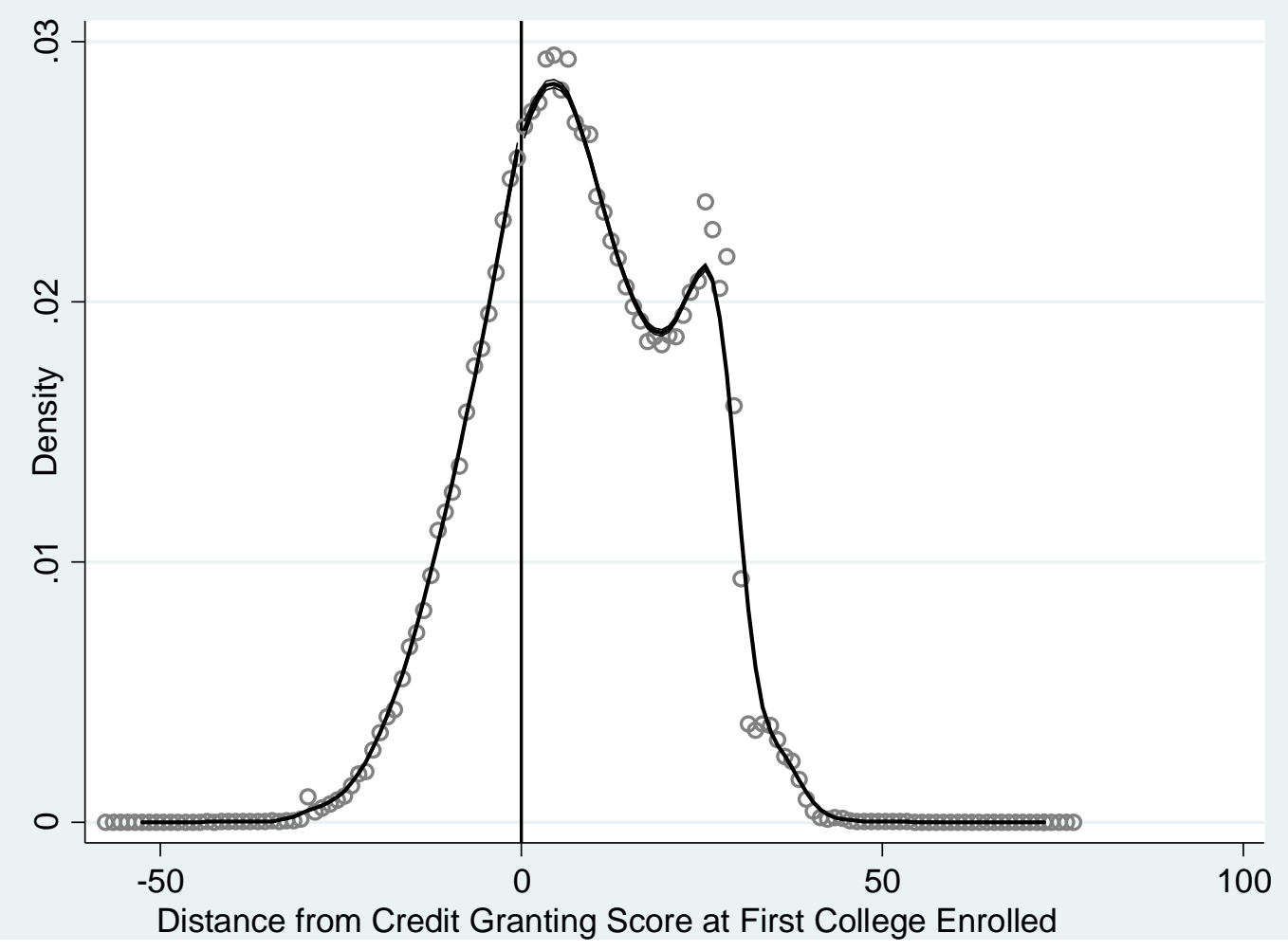


Figure 3: Impact of CLEP credit on time to degree
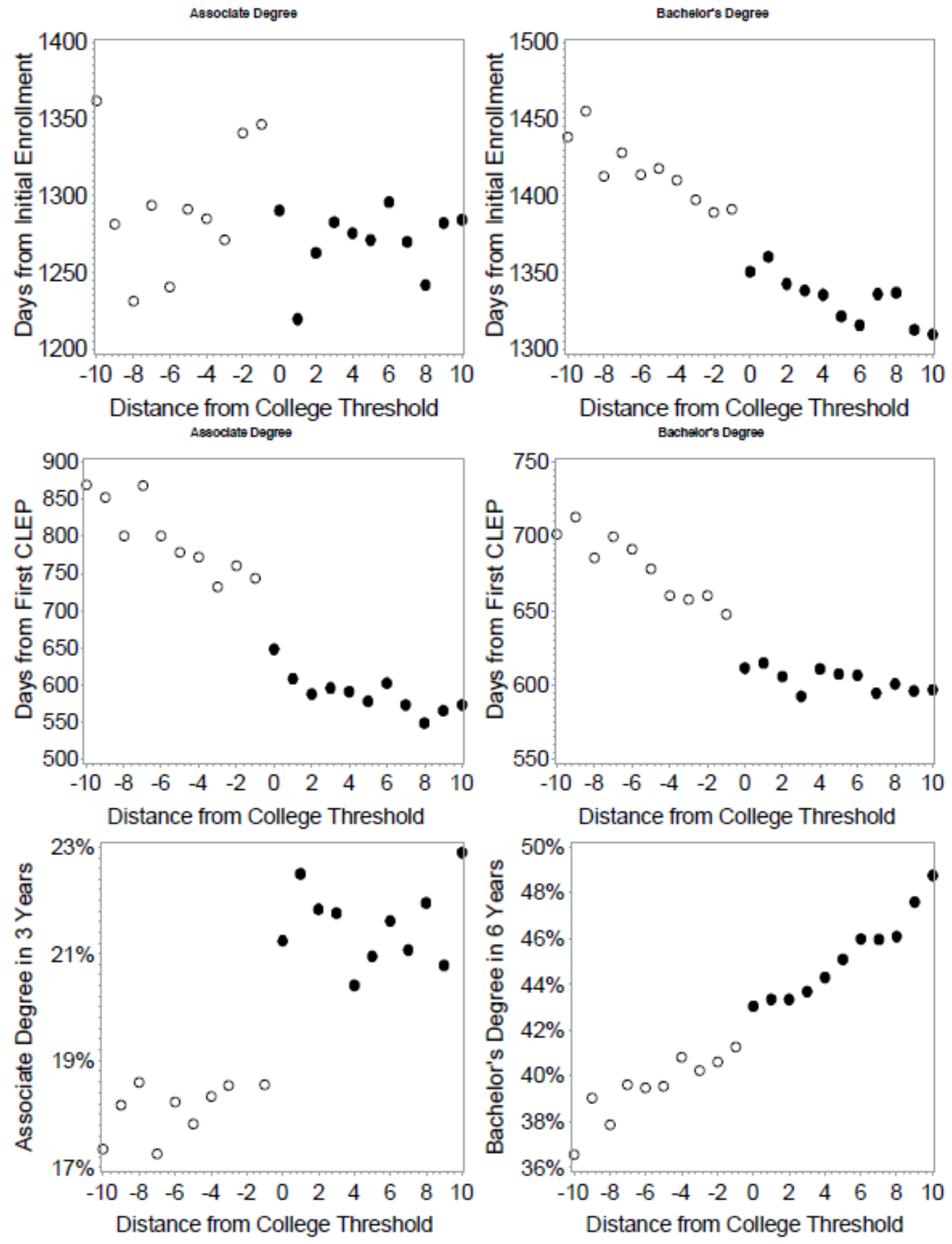
Figure 4: Impact of CLEP credit on exam retaking, subsequent exams, and total exams passed
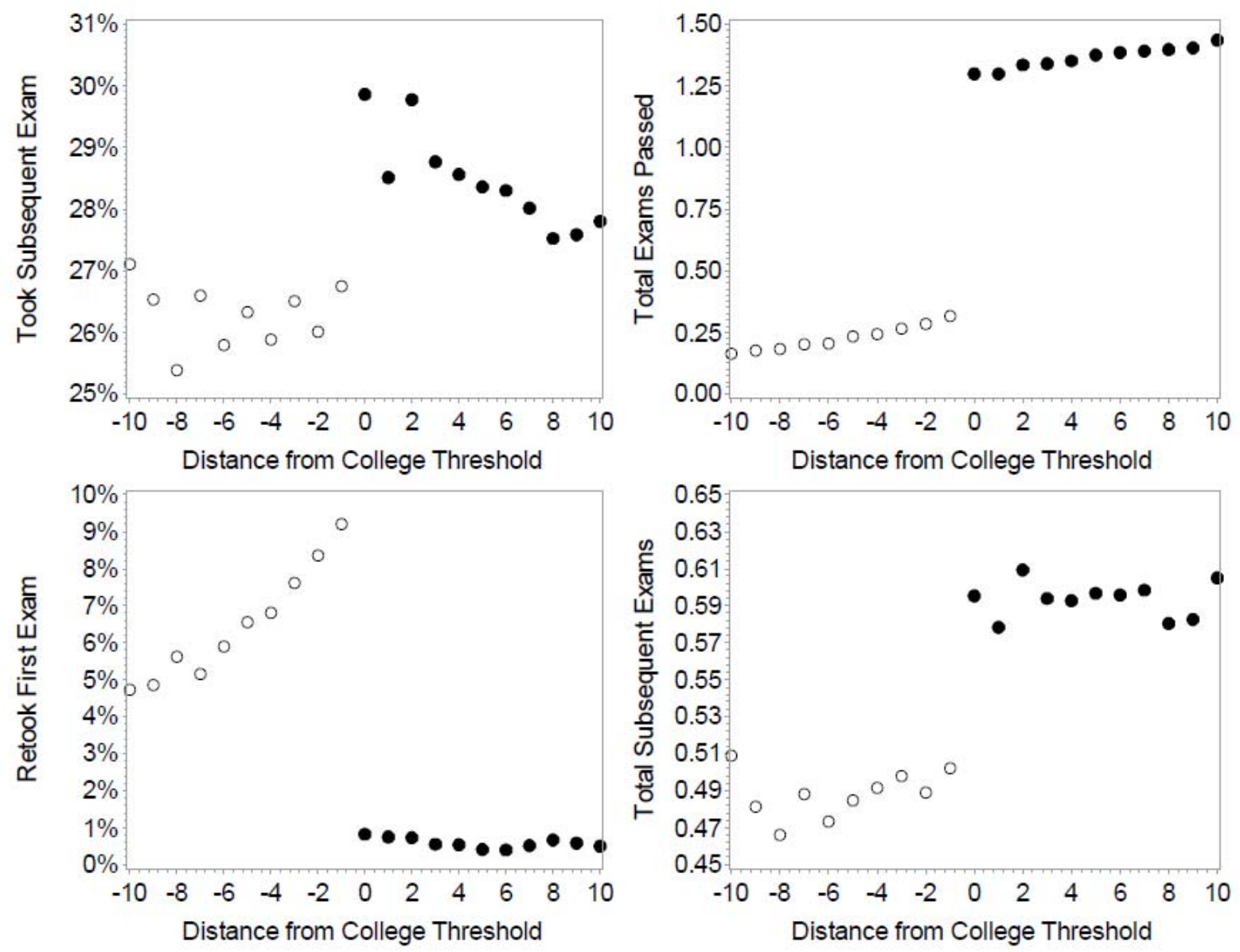
Figure 5: Impact of second CLEP exam on completion.

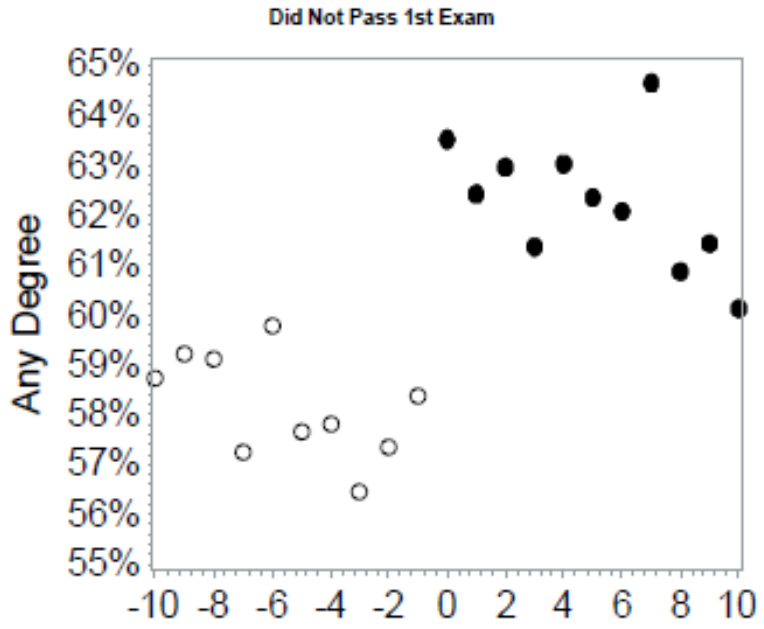

Dist. from Coll. Threshold (2nd Exam) Did Not Pass 1st Exam

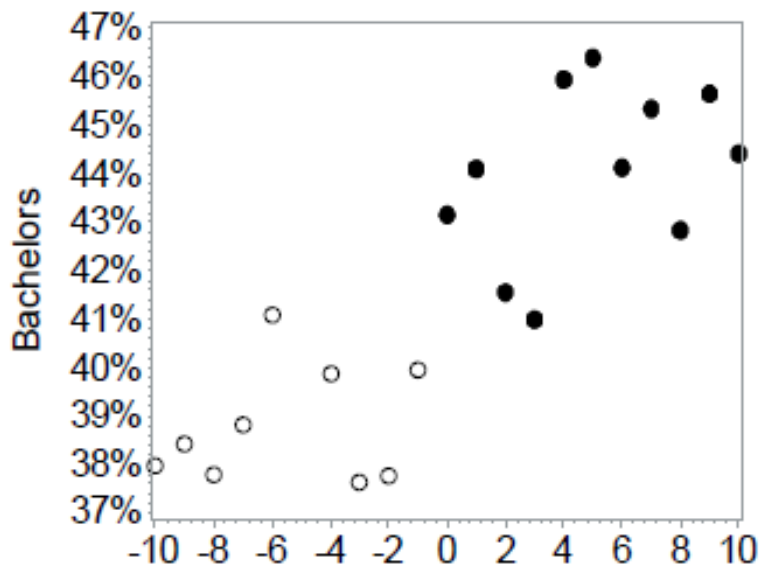

Dist. from Coll. Threshold (2nd Exam) Did Not Pass 1st Exam

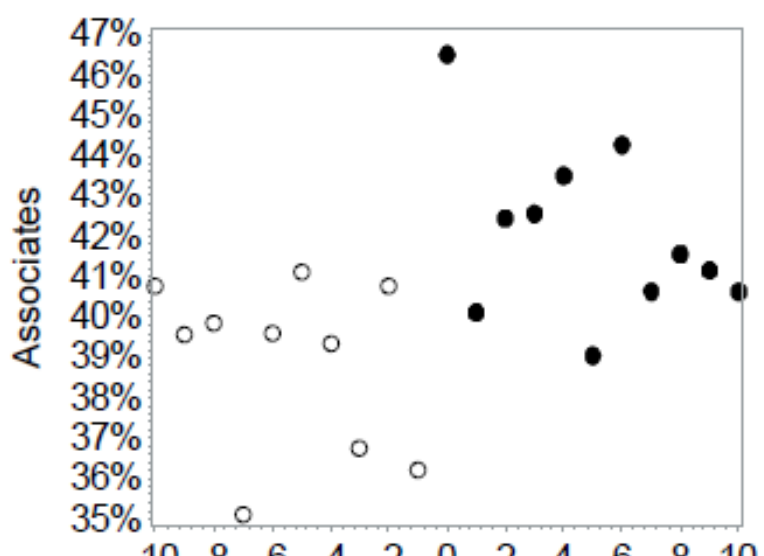

$\begin{array}{lllllllllll}-10 & -8 & -6 & -4 & -2 & 0 & 2 & 4 & 6 & 8 & 10\end{array}$

Dist. from Coll. Threshold (2nd Exam)

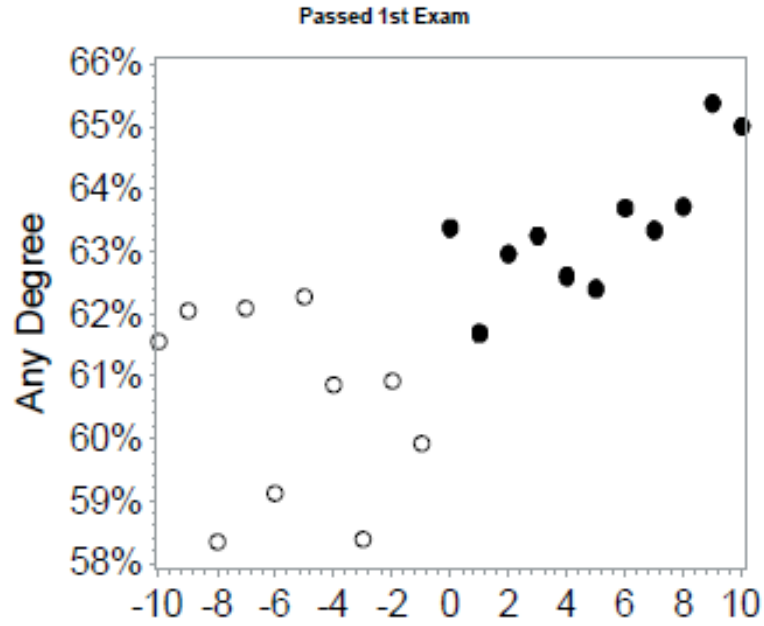

Dist. from Coll. Threshold (2nd Exam) Passed 1st Exam

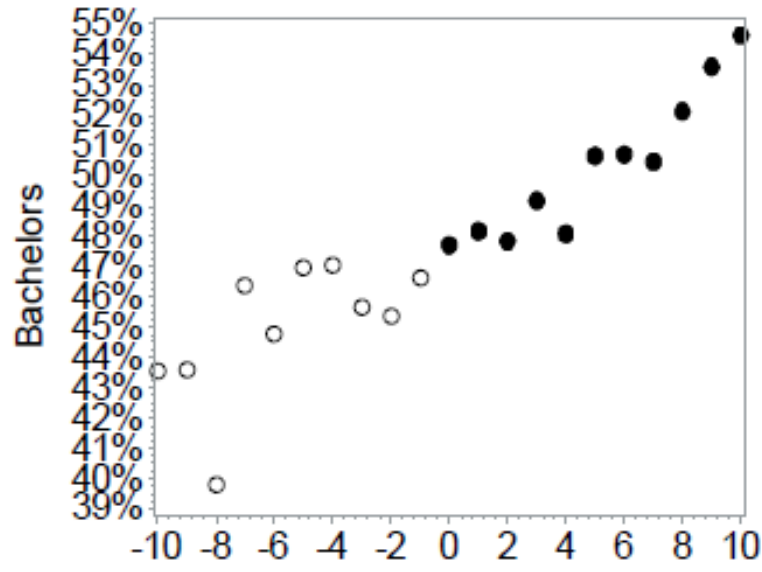

Dist. from Coll. Threshold (2nd Exam)

Passed 1st Exam

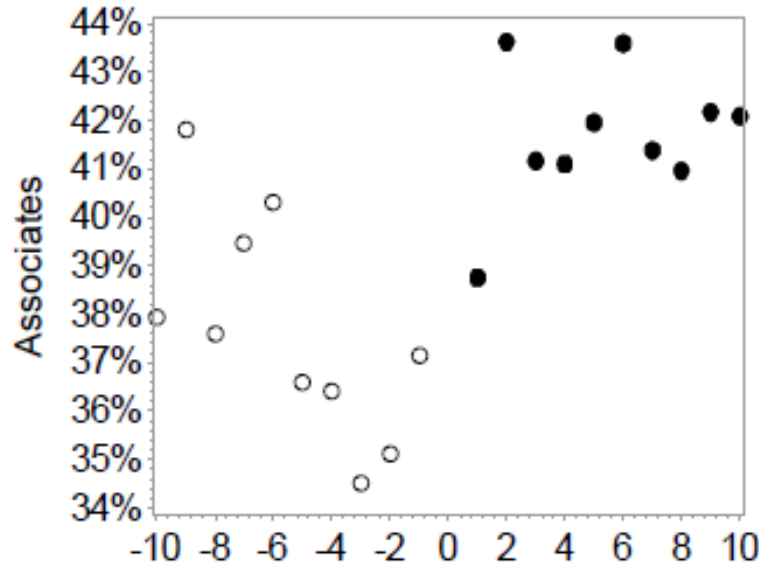

Dist. from Coll. Threshold (2nd Exam) 
Figure 6a: Eventual College Enrollment Among Students Not Enrolled when Taking CLEP, by CLEP Forcing Variables
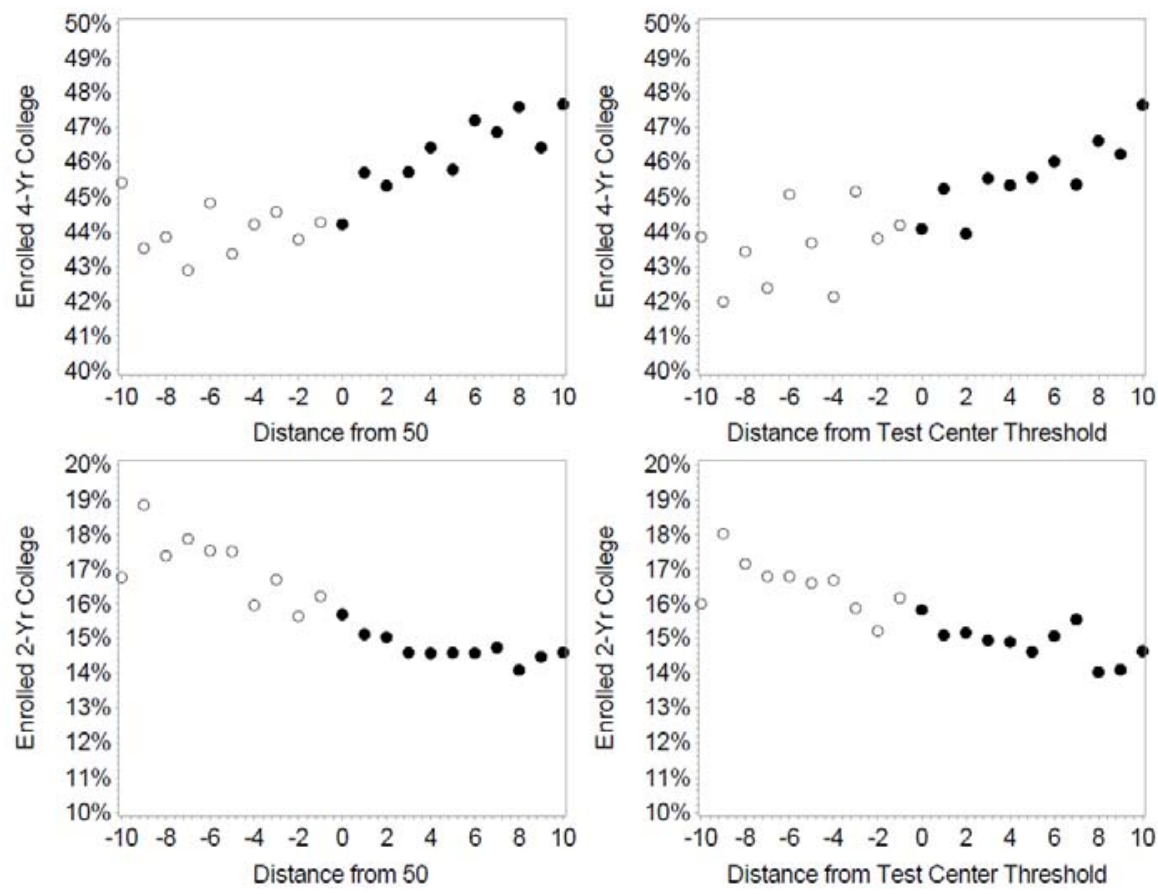

Figure 6b: College Enrollment Among All Students, by CLEP Forcing Variables
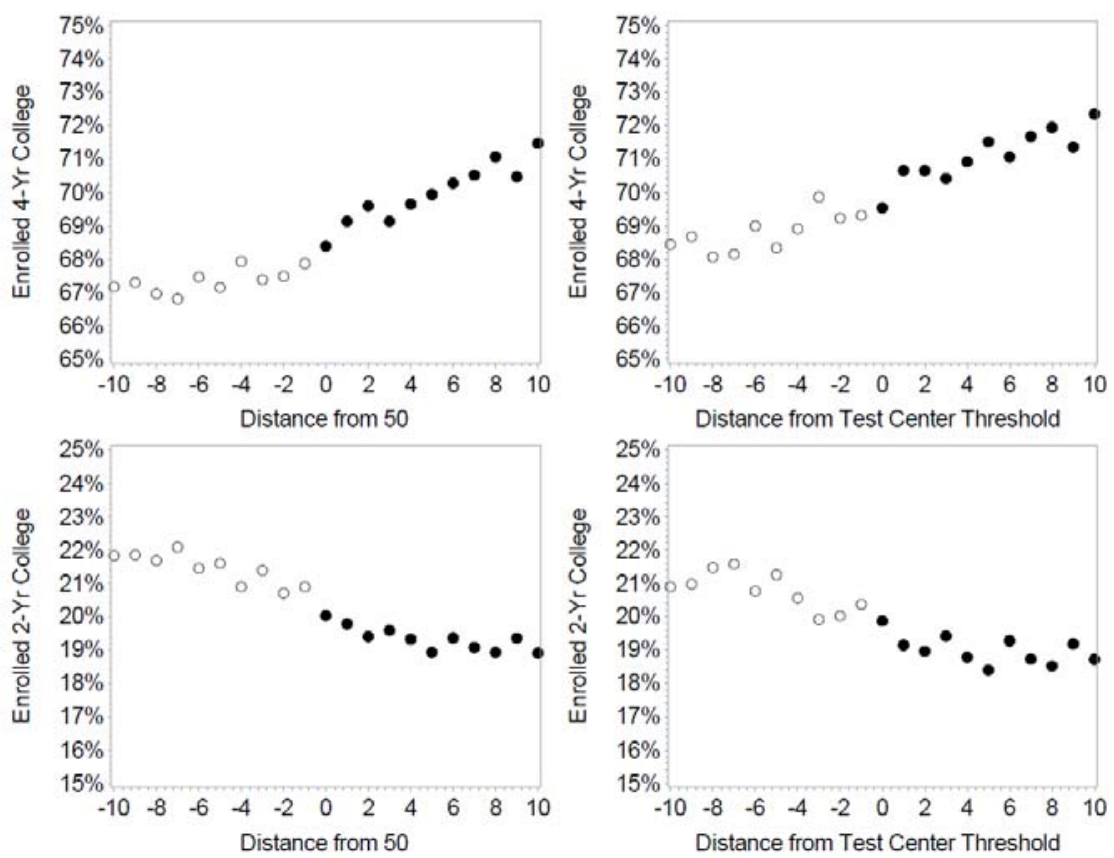
Figure 7: Heterogeneous impacts of earning minimum credit-granting CLEP scores
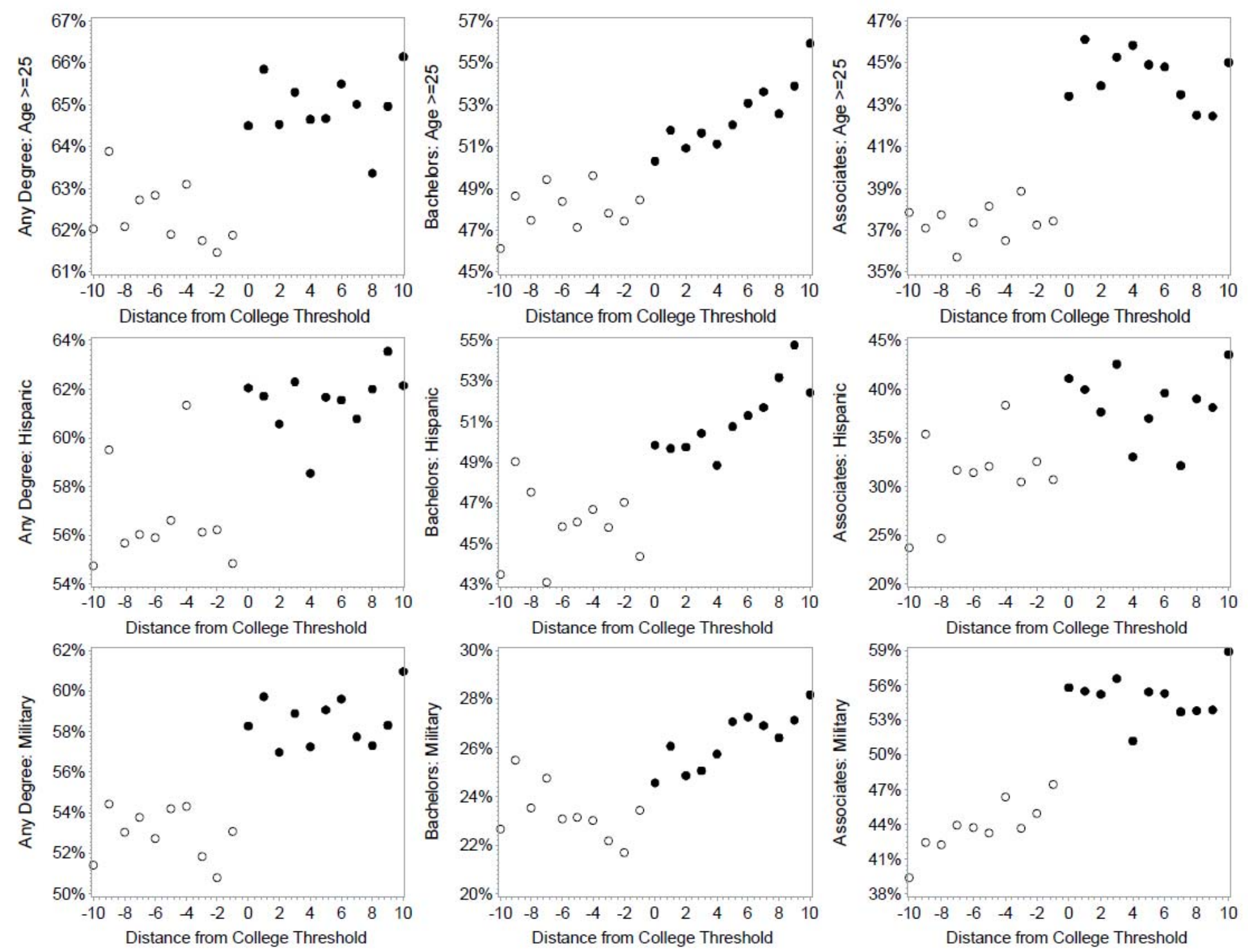
Appendix Table 1: First CLEP Exams Statistics

\begin{tabular}{|c|c|c|c|c|}
\hline Exam & Freq. & $\underline{\text { Percent }}$ & Avg. Score & Std. Dev. \\
\hline Spanish Language & 199,228 & 24.56 & 68.91 & 10.11 \\
\hline Analyzing and Interpreting Lit & 82,615 & 10.19 & 57.97 & 9.85 \\
\hline College Algebra & 52,345 & 6.45 & 49.63 & 12.43 \\
\hline College Mathematics & 41,132 & 5.07 & 52.80 & 12.25 \\
\hline College Composition & 41,114 & 5.07 & 54.19 & 5.80 \\
\hline College Composition Modular & 28,732 & 3.54 & 55.50 & 6.79 \\
\hline Introductory Sociology & 28,161 & 3.47 & 53.70 & 7.44 \\
\hline Principles of Management & 24,786 & 3.06 & 49.67 & 10.80 \\
\hline History of United States I & 23,681 & 2.92 & 51.65 & 10.66 \\
\hline Biology & 20,148 & 2.48 & 53.29 & 10.01 \\
\hline Introductory Psychology & 20,051 & 2.47 & 57.02 & 9.75 \\
\hline English Composition & 19,039 & 2.35 & 46.50 & 11.36 \\
\hline Humanities & 18,131 & 2.24 & 49.85 & 8.79 \\
\hline French Language & 17,981 & 2.22 & 65.09 & 11.89 \\
\hline Human Growth and Development & 17,585 & 2.17 & 53.88 & 7.85 \\
\hline Info Systems and Computer Appl & 17,172 & 2.12 & 53.61 & 11.22 \\
\hline Freshman College Composition & 17,012 & 2.10 & 57.17 & 11.00 \\
\hline American Government & 15,923 & 1.96 & 47.43 & 11.70 \\
\hline English Composition with Essay & 14,491 & 1.79 & 51.70 & 10.67 \\
\hline History of United States II & 14,375 & 1.77 & 49.85 & 9.78 \\
\hline Natural Sciences & 12,245 & 1.51 & 48.00 & 9.51 \\
\hline Principles of Marketing & 11,262 & 1.39 & 55.94 & 10.78 \\
\hline Social Sciences and History & 8,068 & 0.99 & 48.84 & 10.72 \\
\hline Precalculus & 6,739 & 0.83 & 52.82 & 10.40 \\
\hline German Language & 6,656 & 0.82 & 64.80 & 14.84 \\
\hline American Literature & 6,266 & 0.77 & 45.86 & 12.55 \\
\hline Western Civilization I & 6,046 & 0.75 & 54.48 & 9.03 \\
\hline Principles of Microeconomics & 5,445 & 0.67 & 51.64 & 13.50 \\
\hline Calculus & 5,345 & 0.66 & 53.25 & 12.32 \\
\hline Principles of Macroeconomics & 5,186 & 0.64 & 51.92 & 12.75 \\
\hline Chemistry & 4,976 & 0.61 & 46.44 & 11.48 \\
\hline Intro to Educational Psych & 4,233 & 0.52 & 50.62 & 12.16 \\
\hline English Literature & 3,852 & 0.47 & 49.94 & 10.32 \\
\hline Western Civilization II & 3,788 & 0.47 & 50.39 & 8.62 \\
\hline Financial Accounting & 3,688 & 0.45 & 49.41 & 12.88 \\
\hline Introductory Business Law & 3,606 & 0.44 & 46.90 & 12.51 \\
\hline
\end{tabular}




\begin{tabular}{ccc}
\multicolumn{3}{c}{ IV Estimates } \\
\hline First Stage & Second Stage \\
\end{tabular}

\begin{tabular}{|c|c|c|c|c|c|}
\hline All & Two-Year & Four-Year & All & Two-Year & Four-Year \\
\hline Students & Students & Students & Students & Students & Students \\
\hline
\end{tabular}

$\begin{array}{lllll}\text { (1) (2) (3) (4) } & \text { (5) }\end{array}$

\begin{tabular}{|c|c|c|c|c|c|c|}
\hline \multirow[b]{2}{*}{ Above Threshold/Total Exams } & \multicolumn{6}{|c|}{ Panel A: Any Degree } \\
\hline & & & & & & \\
\hline Passed & $\begin{array}{c}0.961^{* * *} \\
(0.008)\end{array}$ & $\begin{array}{c}0.999 * * * \\
(0.014)\end{array}$ & $\begin{array}{l}0.953^{* * *} \\
(0.009)\end{array}$ & $\begin{array}{c}0.031^{* * *} \\
(0.005)\end{array}$ & $\begin{array}{c}0.034^{* * *} \\
(0.009)\end{array}$ & $\begin{array}{c}0.030^{* * *} \\
(0.005)\end{array}$ \\
\hline Observations & 243,845 & 63,186 & 195,865 & 243,845 & 63,186 & 195,865 \\
\hline \multirow[t]{2}{*}{$\begin{array}{l}\text { Optimal Bandwidth } \\
\text { Control Mean }\end{array}$} & $\begin{array}{l}7.174 \\
0.342\end{array}$ & $\begin{array}{l}10.180 \\
0.283\end{array}$ & $\begin{array}{l}7.641 \\
0.357\end{array}$ & $\begin{array}{l}7.174 \\
0.562\end{array}$ & $\begin{array}{l}10.180 \\
0.485\end{array}$ & $\begin{array}{l}7.641 \\
0.582\end{array}$ \\
\hline & \multicolumn{6}{|c|}{ Panel B: Associate's Degree } \\
\hline \multicolumn{7}{|l|}{ Above Threshold/ Total Exams } \\
\hline Passed & $\begin{array}{c}0.960^{* * *} \\
(0.008)\end{array}$ & $\begin{array}{c}0.999 * * * \\
(0.013)\end{array}$ & $\begin{array}{c}0.957^{* * *} \\
(0.008)\end{array}$ & $\begin{array}{c}0.031^{* * *} \\
(0.004)\end{array}$ & $\begin{array}{c}0.057^{* * *} \\
(0.008)\end{array}$ & $\begin{array}{c}0.022^{* * *} \\
(0.004)\end{array}$ \\
\hline Observations & 214,869 & 67,840 & 217,605 & 214,869 & 67,840 & 217,605 \\
\hline \multirow[t]{2}{*}{ Control Mean } & $\begin{array}{l}6.940 \\
0.342\end{array}$ & $\begin{array}{l}11.086 \\
0.283\end{array}$ & $\begin{array}{l}8.934 \\
0.357\end{array}$ & $\begin{array}{l}6.940 \\
0.197\end{array}$ & $\begin{array}{l}11.086 \\
0.329\end{array}$ & $\begin{array}{l}8.934 \\
0.163\end{array}$ \\
\hline & \multicolumn{6}{|c|}{ Panel C: Bachelor's Degree } \\
\hline \multicolumn{7}{|l|}{ Above Threshold/Total Exams } \\
\hline Passed & $\begin{array}{c}0.978^{* * *} \\
(0.006)\end{array}$ & $\begin{array}{c}0.999 * * * \\
(0.015)\end{array}$ & $\begin{array}{c}0.968 * * * \\
(0.007)\end{array}$ & $\begin{array}{c}0.006 \\
(0.004)\end{array}$ & $\begin{array}{l}-0.016^{* *} \\
(0.008)\end{array}$ & $\begin{array}{c}0.012^{* * *} \\
(0.004)\end{array}$ \\
\hline Observations & 365,599 & 53,232 & 276,034 & 365,599 & 53,232 & 276,034 \\
\hline Optimal Bandwidth & 12.935 & 8.509 & 11.848 & 12.935 & 8.509 & 11.848 \\
\hline Control Mean & 0.342 & 0.283 & 0.357 & 0.407 & 0.203 & 0.459 \\
\hline
\end{tabular}

Notes: Heteroskedasticity robust standard errors are in parentheses $(* p<.10 * * p<.05 * * * p<.01)$. Columns $4-6$ present instrumental variables estimates of the total exams passed on college completion, where total exams passed is instrumented by whether the student earned a credit-granting CLEP score on the first exam. The parameter estimate shown in these three columns reflects the discontinuity in the outcome associated with the binary Credit variable in Equation 1. Control means represent the averages 1 point below the cut score at the enrolling institution. We use triangular kernels in the regression discontinuity models. 
Forcing Variable (1) - Distance Credit Granting Score at Testing Center From 50 College

\begin{tabular}{|c|c|c|c|c|c|}
\hline$\underline{A l l}$ & $\underline{T w o-Y e a r}$ & Four-Year & $\underline{\text { All }}$ & $\underline{T w o-Y e a r}$ & Four-Year \\
\hline Students & Students & $\overline{\text { Students }}$ & Students & Students & Students \\
\hline (1) & (2) & (3) & (4) & (5) & (6) \\
\hline \multicolumn{6}{|c|}{ Panel 1: Outcome = Any Degree } \\
\hline $\begin{array}{c}0.025^{* * *} \\
(0.004)\end{array}$ & $\begin{array}{c}0.032^{* * *} \\
(0.007)\end{array}$ & $\begin{array}{c}0.028^{* * *} \\
(0.006)\end{array}$ & $\begin{array}{c}0.020^{* * *} \\
(0.005)\end{array}$ & $\begin{array}{c}0.023^{* * *} \\
(0.008)\end{array}$ & $\begin{array}{c}0.023^{* * *} \\
(0.006)\end{array}$ \\
\hline 316,460 & 95,730 & 163,845 & 244,613 & 68,085 & 151,071 \\
\hline $\begin{array}{l}7.944 \\
0.498\end{array}$ & $\begin{array}{c}12.666 \\
0.467\end{array}$ & $\begin{array}{l}5.976 \\
0.582\end{array}$ & $\begin{array}{l}7.675 \\
0.487\end{array}$ & $\begin{array}{c}11.341 \\
0.468\end{array}$ & $\begin{array}{l}6.469 \\
0.573\end{array}$ \\
\hline \multicolumn{6}{|c|}{ Panel 2: Outcome $=$ Associate's Degree } \\
\hline $\begin{array}{c}0.023^{* * *} \\
(0.003)\end{array}$ & $\begin{array}{c}0.053 * * * \\
(0.007)\end{array}$ & $\begin{array}{c}0.019 * * * \\
(0.003)\end{array}$ & $\begin{array}{c}0.019 * * * \\
(0.003)\end{array}$ & $\begin{array}{c}0.045^{* * *} \\
(0.008)\end{array}$ & $\begin{array}{c}0.015^{* * *} \\
(0.004)\end{array}$ \\
\hline 316,460 & 83,792 & 241,893 & 244,613 & 63,381 & 190,911 \\
\hline $\begin{array}{l}7.013 \\
0.169\end{array}$ & $\begin{array}{c}10.102 \\
0.307\end{array}$ & $\begin{array}{l}8.825 \\
0.153\end{array}$ & $\begin{array}{l}7.914 \\
0.176\end{array}$ & $\begin{array}{c}10.903 \\
0.312\end{array}$ & $\begin{array}{l}8.545 \\
0.163\end{array}$ \\
\hline \multicolumn{6}{|c|}{ Panel 3: Outcome $=$ Bachelor's Degree } \\
\hline $\begin{array}{l}0.010^{* *} \\
(0.004)\end{array}$ & $\begin{array}{l}-0.011 \\
(0.008)\end{array}$ & $\begin{array}{c}0.015^{* * *} \\
(0.005)\end{array}$ & $\begin{array}{c}0.004 \\
(0.004)\end{array}$ & $\begin{array}{c}-0.017^{* *} \\
(0.007)\end{array}$ & $\begin{array}{l}0.012^{* *} \\
(0.005)\end{array}$ \\
\hline 278,844 & 56,161 & 191,555 & 298,400 & 58,711 & 190,911 \\
\hline $\begin{array}{l}6.594 \\
0.365\end{array}$ & $\begin{array}{l}6.555 \\
0.204\end{array}$ & $\begin{array}{l}6.823 \\
0.467\end{array}$ & $\begin{array}{l}9.880 \\
0.346\end{array}$ & $\begin{array}{l}9.125 \\
0.198\end{array}$ & $\begin{array}{l}8.144 \\
0.450\end{array}$ \\
\hline
\end{tabular}

Above Threshold

Observations

Optimal Bandwidth

Control Mean

Above Threshold

Observations

Optimal Bandwidth

Control Mean

Above Threshold

Observations

Optimal Bandwidth

Control Mean

0.365

0.204

0.346

0.198

0.450

Notes: Heteroskedasticity robust standard errors are in parentheses $\left({ }^{*} p<.10^{* *} p<.05^{* * *} p<.01\right)$. Each estimate comes from a local linear regression with a triangular kernel of the outcomes on the forcing variables indicated by the column headers, an indicator variable for whether the forcing variable is greater than or equal to 0 (i.e. eligible for credit) and the interaction of these two terms. 
Appendix Table 5: Robustness Tests for Impact of Receiving CLEP Credit on Degree Attainment

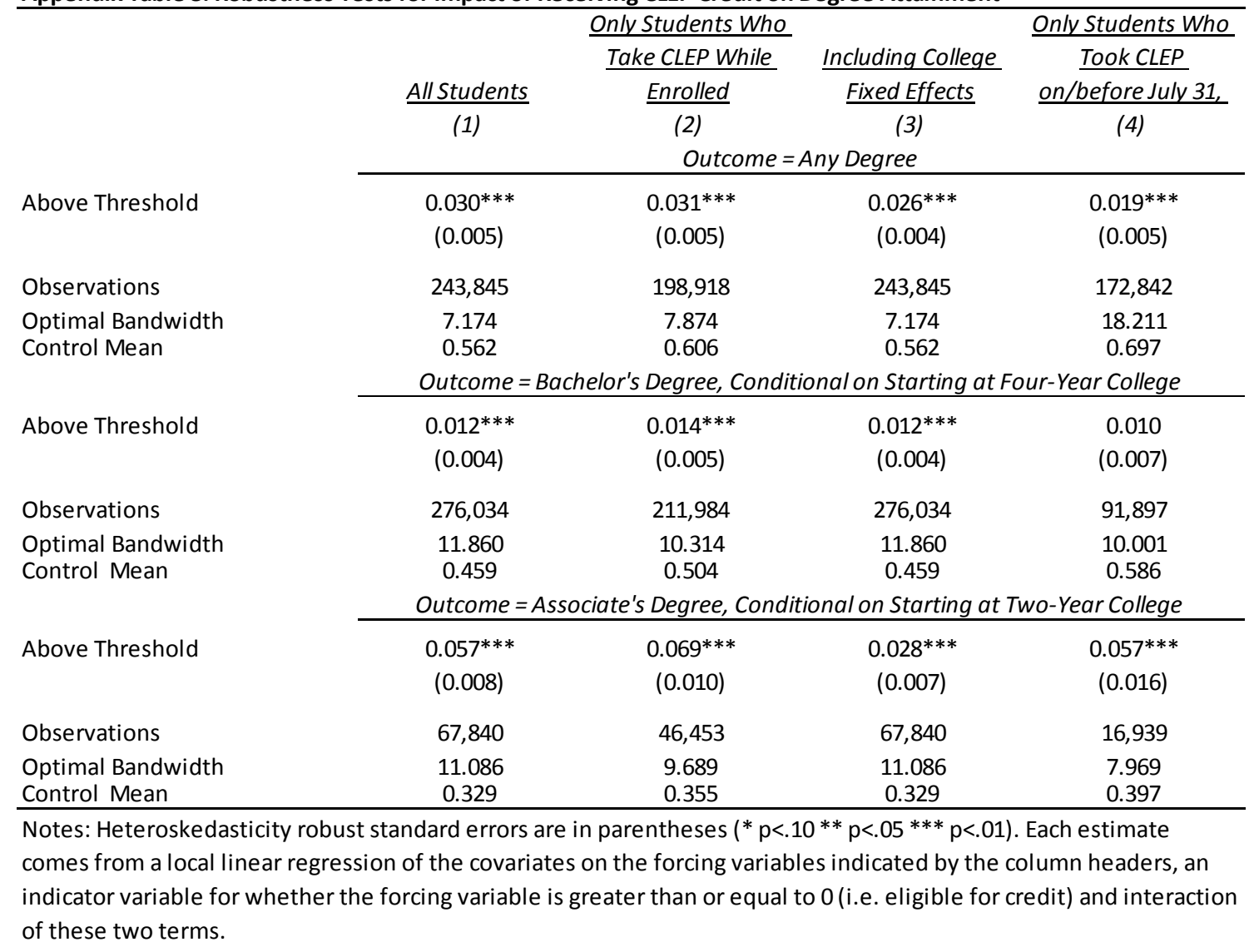


Appendix Table 6: Impact of Receiving CLEP Credit for Spanish Exam Takers

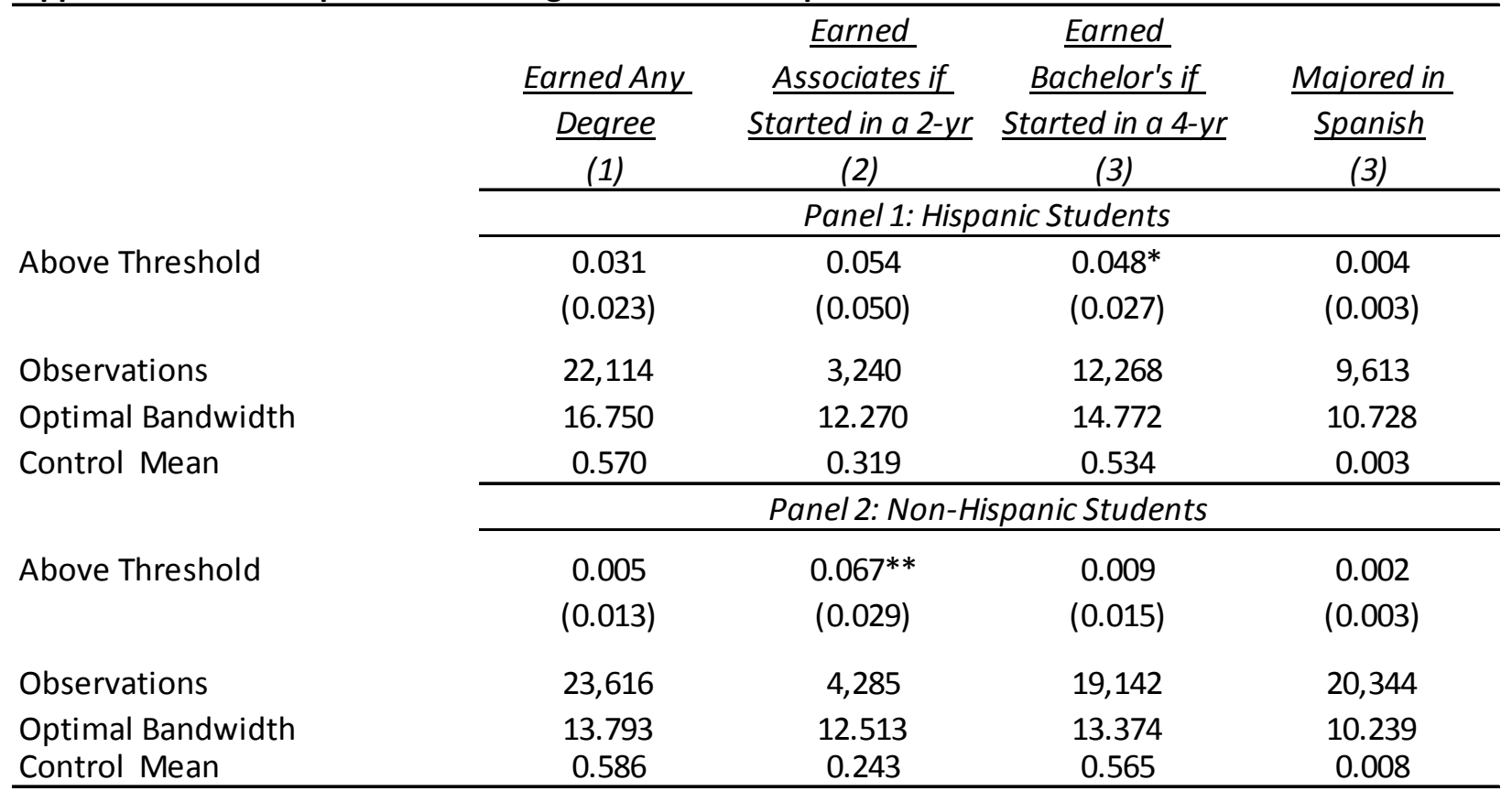

Notes: Heteroskedasticity robust standard errors are in parentheses $\left(* p<.10^{* *} p<.05 * * * p<.01\right)$. Each estimate comes from a local linear regression of the covariates on the forcing variables indicated by the column headers, an indicator variable for whether the forcing variable is greater than or equal to 0 (i.e. eligible for credit) and interaction of these two terms. 
Appendix Figure 1: Density of Observations, by Alternate Forcing Variables
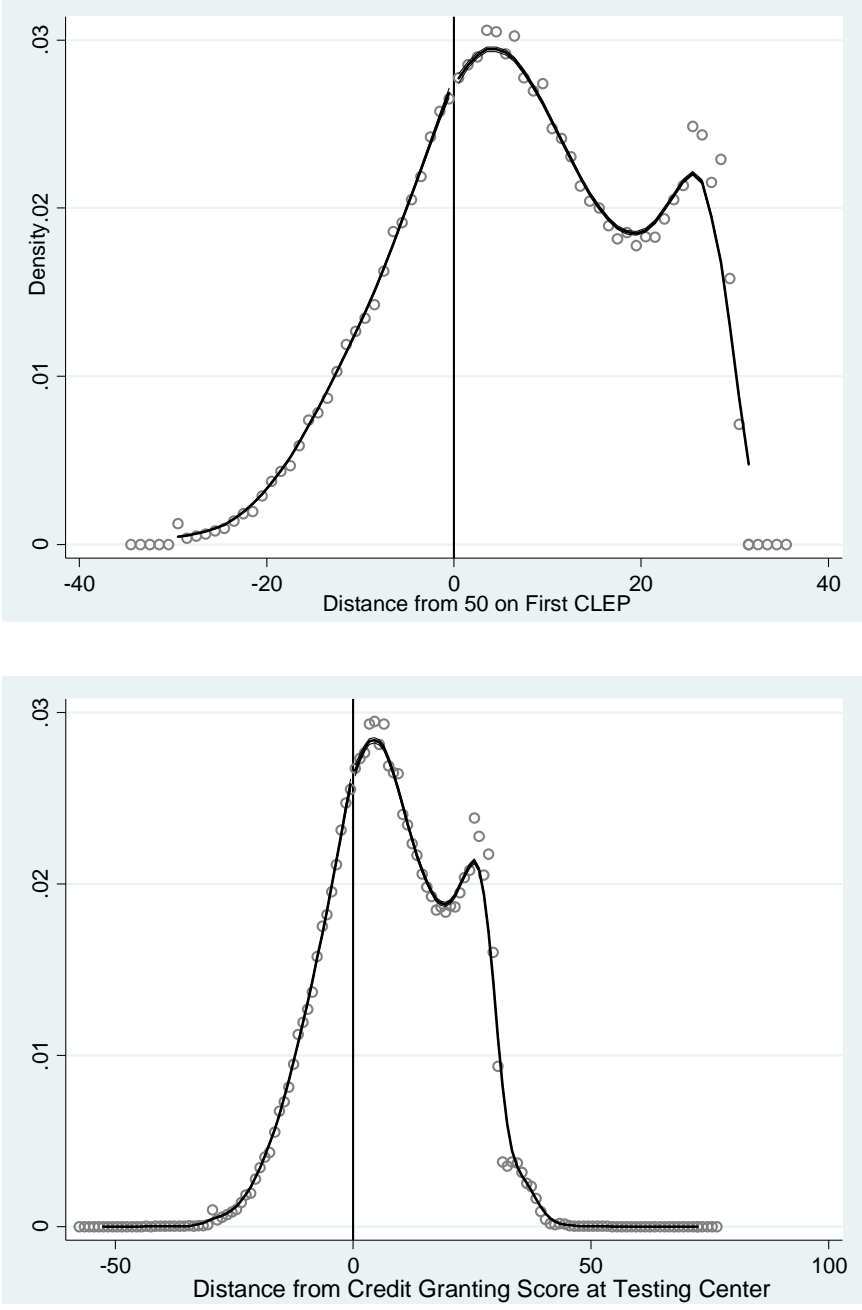

50 
Appendix Figure 2: College Completion, by Alternate Forcing Variables
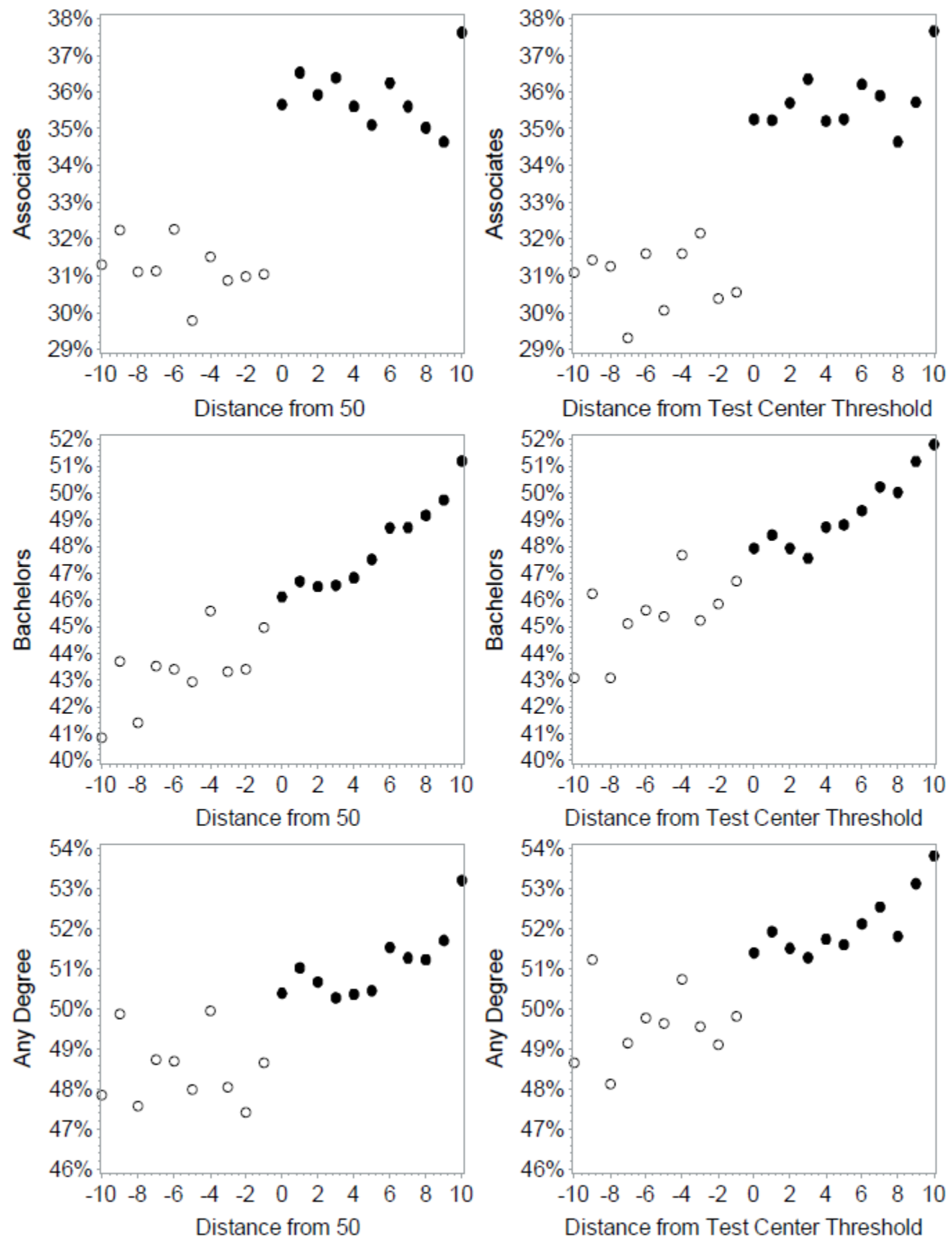